\title{
LEVEL II SCOUR ANALYSIS FOR BRIDGE 94 (FERDVT01050094) on STATE ROUTE 105, crossing the NULHEGAN RIVER, FERDINAND, VERMONT
}

U.S. Geological Survey Open-File Report 96-586

Prepared in cooperation with

VERMONT AGENCY OF TRANSPORTATION and

FEDERAL HIGHWAY ADMINISTRATION 


\section{LEVEL II SCOUR ANALYSIS FOR BRIDGE 94 (FERDVT01050094) on STATE ROUTE 105, crossing the NULHEGAN RIVER, FERDINAND, VERMONT}

By Erick M. Boehmler and James R. Degnan

U.S. Geological Survey

Open-File Report 96-586

Prepared in cooperation with

VERMONT AGENCY OF TRANSPORTATION

and

FEDERAL HIGHWAY ADMINISTRATION 


\title{
U.S. DEPARTMENT OF THE INTERIOR BRUCE BABBITT, Secretary
}

\author{
U.S. GEOLOGICAL SURVEY \\ Gordon P. Eaton, Director
}

For additional information write to:

District Chief

U.S. Geological Survey 361 Commerce Way

Pembroke, NH 03275-3718
Copies of this report may be purchased from:

U.S. Geological Survey

Branch of Information Services

Open-File Reports Unit

Box 25286

Denver, CO 80225-0286 


\section{CONTENTS}

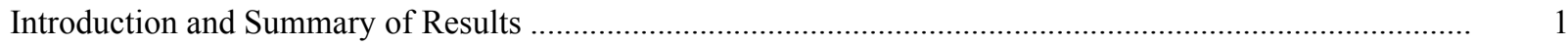

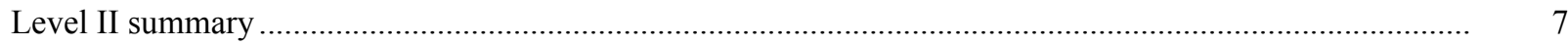

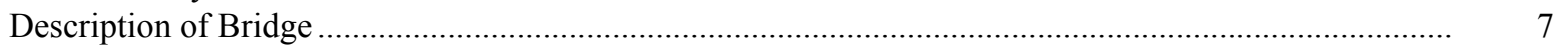

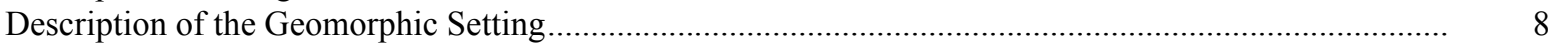

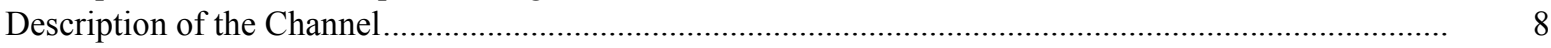

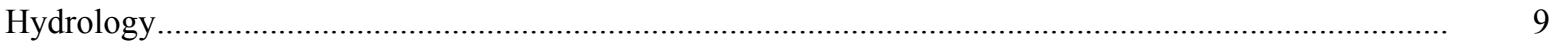

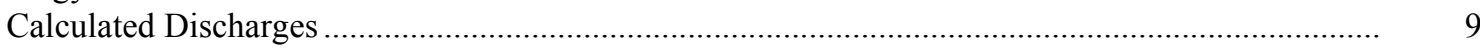

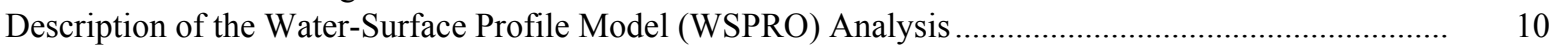

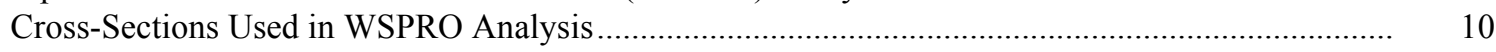

Data and Assumptions Used in WSPRO Model ...................................................................... 11

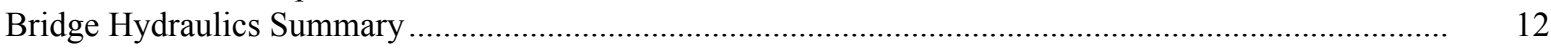

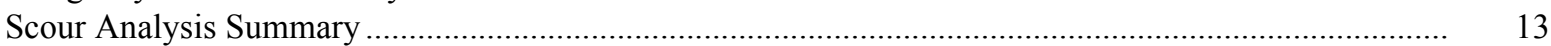

Special Conditions or Assumptions Made in Scour Analysis ...................................................... 13

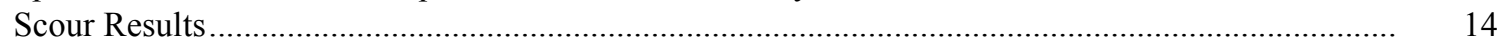

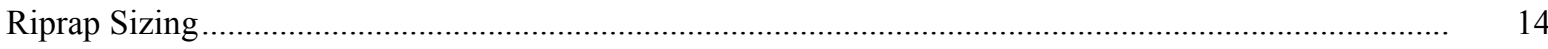

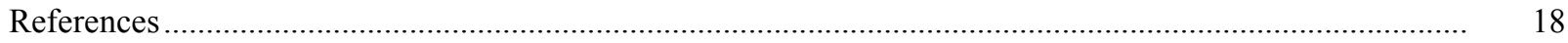

Appendixes:

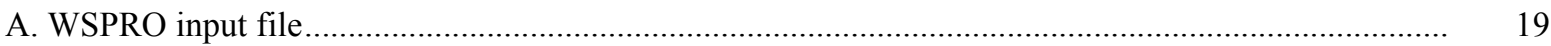

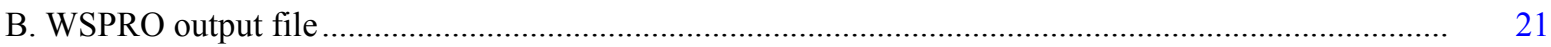

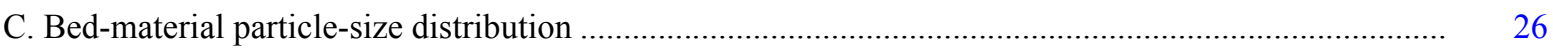

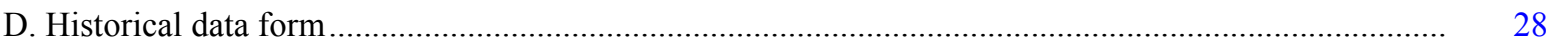

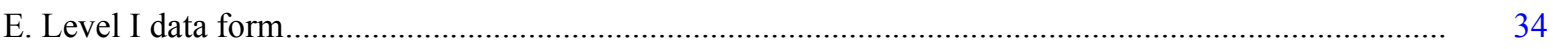

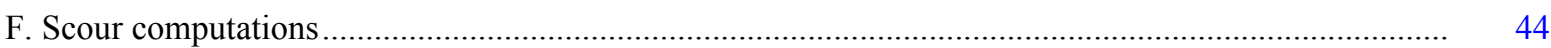

\section{FIGURES}

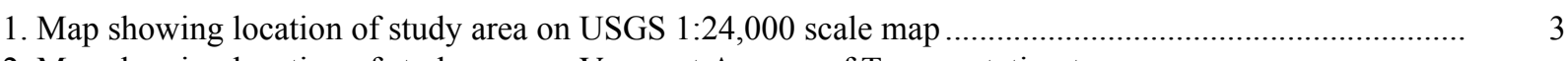

2. Map showing location of study area on Vermont Agency of Transportation town

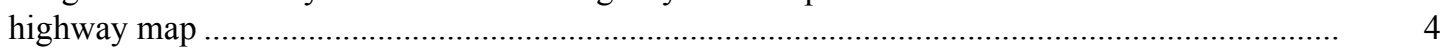

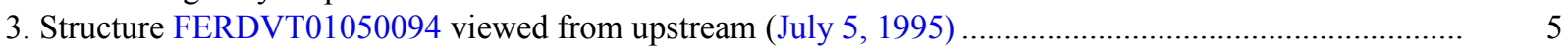

4. Downstream channel viewed from structure FERDVT01050094 (July 5, 1995)................................. 5

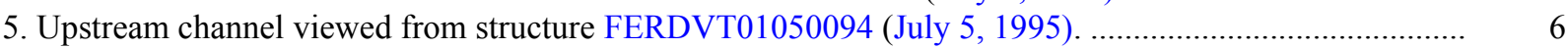

6. Structure FERDVT01050094 viewed from downstream (July 5, 1995) ............................................

7. Water-surface profiles for the 100- and 500-year discharges at structure FERDVT01050094 on State Route 105, crossing the Nulhegan River,

Ferdinand, Vermont.

8. Scour elevations for the 100- and 500-year discharges at structure

FERDVT01050094 on State Route 105, crossing the Nulhegan River,

Ferdinand, Vermont.

\section{TABLES}

1. Remaining footing/pile depth at abutments for the 100-year discharge at structure

FERDVT01050094 on State Route 105, crossing the Nulhegan River,

Ferdinand, Vermont

2. Remaining footing/pile depth at abutments for the 500-year discharge at structure

FERDVT01050094 on State Route 105, crossing the Nulhegan River,

Ferdinand, Vermont 


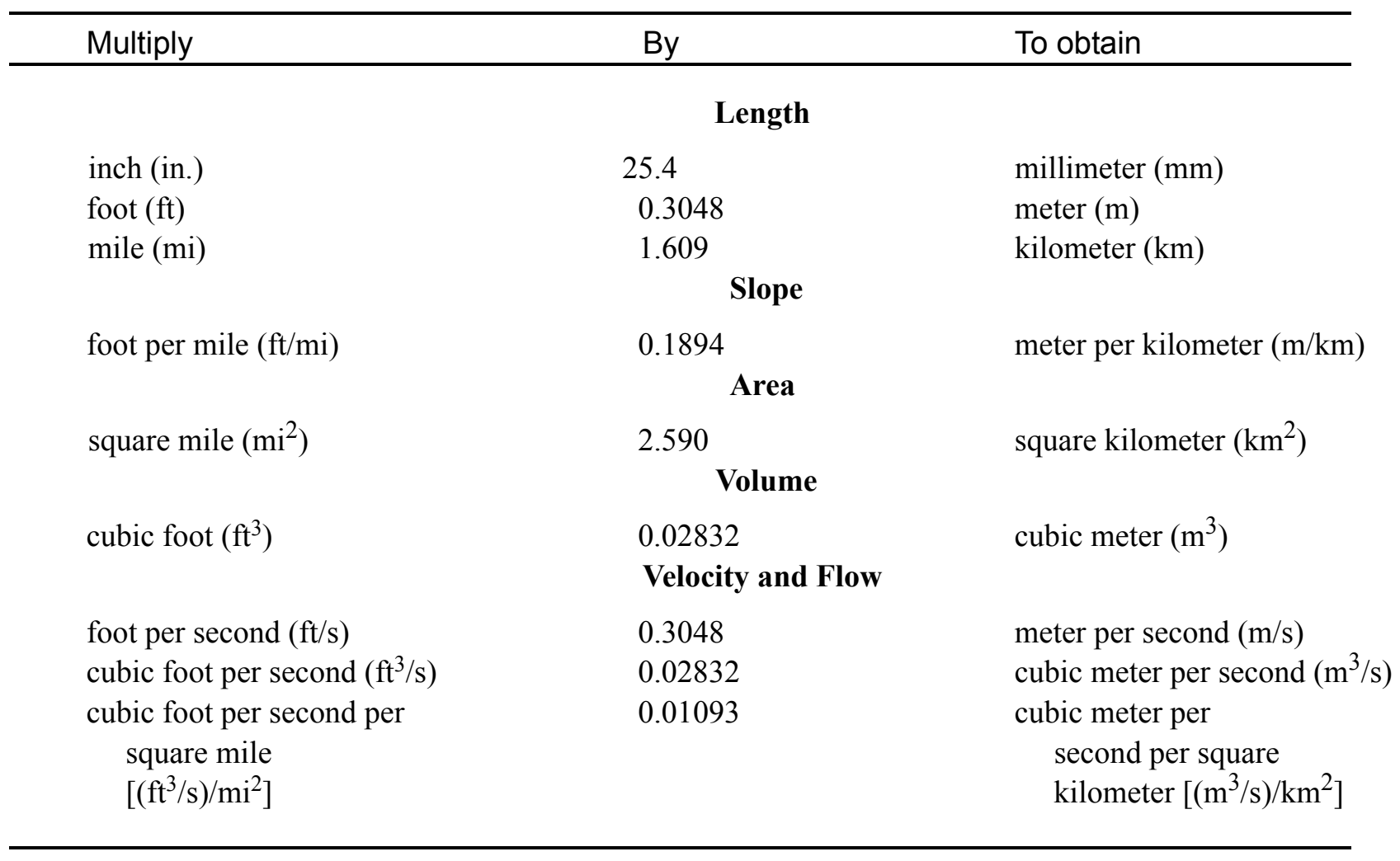

\section{OTHER ABBREVIATIONS}

$\begin{array}{lrlr}\mathrm{BF} & \text { bank full } & \text { LWW } & \text { left wingwall } \\ \mathrm{cfs} & \text { cubic feet per second } & \text { MC } & \text { main channel } \\ \mathrm{D}_{50} & \text { median diameter of bed material } & \text { RAB } & \text { right abutment } \\ \mathrm{DS} & \text { downstream } & \text { RABUT } & \text { face of right abutment } \\ \mathrm{elev} & \text { elevation } & \text { RB } & \text { right bank } \\ \mathrm{f} / \mathrm{p} & \text { flood plain } & \text { ROB } & \text { right overbank } \\ \mathrm{ft}^{2} & \text { square feet } & \text { RWW } & \text { right wingwall } \\ \mathrm{ft} / \mathrm{ft} & \text { feet per foot } & \text { TH } & \text { town highway } \\ \mathrm{JCT} & \text { junction } & \text { UB } & \text { under bridge } \\ \mathrm{LAB} & \text { left abutment } & \text { US } & \text { upstream } \\ \mathrm{LABUT} & \text { face of left abutment } & \text { USGS } & \text { United States Geological Survey } \\ \mathrm{LB} & \text { left bank } & \text { VTAOT Vermont Agency of Transportation } \\ \mathrm{LOB} & \text { left overbank } & \text { WSPRO } & \text { water-surface profile model }\end{array}$

In this report, the words "right" and "left" refer to directions that would be reported by an observer facing downstream. Sea level: In this report, "sea level" refers to the National Geodetic Vertical Datum of 1929-- a geodetic datum derived from a general adjustment of the first-order level nets of the United States and Canada, formerly called Sea Level Datum of 1929.

In the appendices, the above abbreviations may be combined. For example, USLB would represent upstream left bank. 


\title{
LEVEL II SCOUR ANALYSIS FOR BRIDGE 94 (FERDVT01050094) ON STATE ROUTE 105, CROSSING THE NULHEGAN RIVER, FERDINAND, VERMONT
}

\author{
By Erick M. Boehmler and James R. Degnan
}

\section{INTRODUCTION AND SUMMARY OF RESULTS}

This report provides the results of a detailed Level II analysis of scour potential at structure FERDVT01050094 on State Route 105 crossing the Nulhegan River, Ferdinand, Vermont (figures 1-8). A Level II study is a basic engineering analysis of the site, including a quantitative analysis of stream stability and scour (U.S. Department of Transportation, 1993). Results of a Level I scour investigation also are included in Appendix E of this report. A Level I investigation provides a qualitative geomorphic characterization of the study site. Information on the bridge, gleaned from Vermont Agency of Transportation (VTAOT) files, was compiled prior to conducting Level I and Level II analyses and is found in Appendix D.

The site is in the White Mountain section of the New England physiographic province in northeastern Vermont. The $38.4-\mathrm{mi}^{2}$ drainage area is in a predominantly rural and forested basin. In the vicinity of the study site, the surface cover is grass and brush with wetlands immediately adjacent to the stream channel.

In the study area, the Nulhegan River has a meandering channel with a slope of approximately $0.002 \mathrm{ft} / \mathrm{ft}$, an average channel top width of $60 \mathrm{ft}$ and an average channel depth of $6 \mathrm{ft}$. The predominant channel bed material is sand with a median grain size $\left(\mathrm{D}_{50}\right)$ of $0.465 \mathrm{~mm}(0.00153 \mathrm{ft})$. The geomorphic assessment at the time of the Level I and Level II site visit on July 5,1995 , indicated that the reach was laterally unstable.

The State Route 105 crossing of the Nulhegan River is a 44-ft-long, two-lane bridge consisting of one 42-foot steel-beam span (Vermont Agency of Transportation, written communication, March 6,1995). The bridge is supported by vertical, concrete abutments with wingwalls. The channel is skewed approximately 10 degrees to the opening while the opening-skew-to-roadway is zero degrees.

Scour protection measures at the site were type- 2 stone fill (less than 36 inches diameter) on the upstream right bank, the upstream right wingwall, the right abutment, the downstream end of the left abutment and the downstream wingwalls. Additional details describing conditions at the site are included in the Level II Summary and Appendices D and E. 
Scour depths and rock rip-rap sizes were computed using the general guidelines described in Hydraulic Engineering Circular 18 (Richardson and others, 1995). Total scour at a highway crossing is comprised of three components: 1) long-term streambed degradation; 2) contraction scour (due to accelerated flow caused by a reduction in flow area at a bridge) and; 3) local scour (caused by accelerated flow around piers and abutments). Total scour is the sum of the three components. Equations are available to compute depths for contraction and local scour and a summary of the results of these computations follows.

Contraction scour for all modelled flows ranged from 1.2 to $1.9 \mathrm{ft}$. The worst-case contraction scour occurred at the 500-year discharge. Abutment scour ranged from 6.6 to $11.0 \mathrm{ft}$. The worst-case abutment scour also occurred at the 500-year discharge. Total scour depths computed for this site were not below the bottom of the footings, except for the 500year discharge model at the left abutment. Additional information on scour depths and depths to armoring are included in the section titled "Scour Results". Scoured-streambed elevations, based on the calculated scour depths, are presented in tables 1 and 2. A crosssection of the scour computed at the bridge is presented in figure 8. Scour depths were calculated assuming an infinite depth of erosive material and a homogeneous particle-size distribution.

It is generally accepted that the Froehlich equation (abutment scour) gives "excessively conservative estimates of scour depths" (Richardson and others, 1995, p. 47). Usually, computed scour depths are evaluated in combination with other information including (but not limited to) historical performance during flood events, the geomorphic stability assessment, existing scour protection measures, and the results of the hydraulic analyses. Therefore, scour depths adopted by VTAOT may differ from the computed values documented herein. 


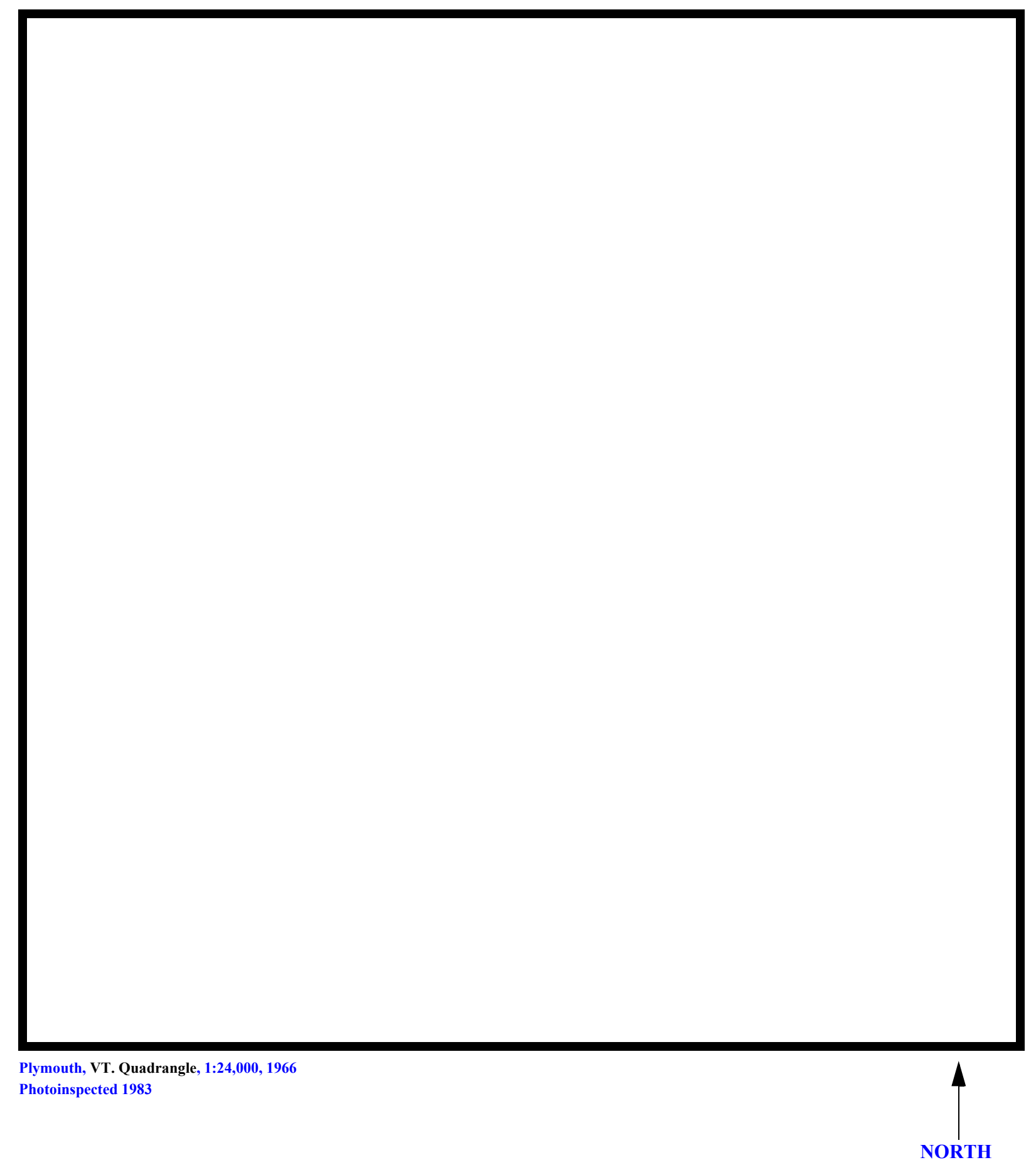

Figure 1. Location of study area on USGS 1:24,000 scale map. 
Figure 2. Location of study area on Vermont Agency of Transportation town highway map. 

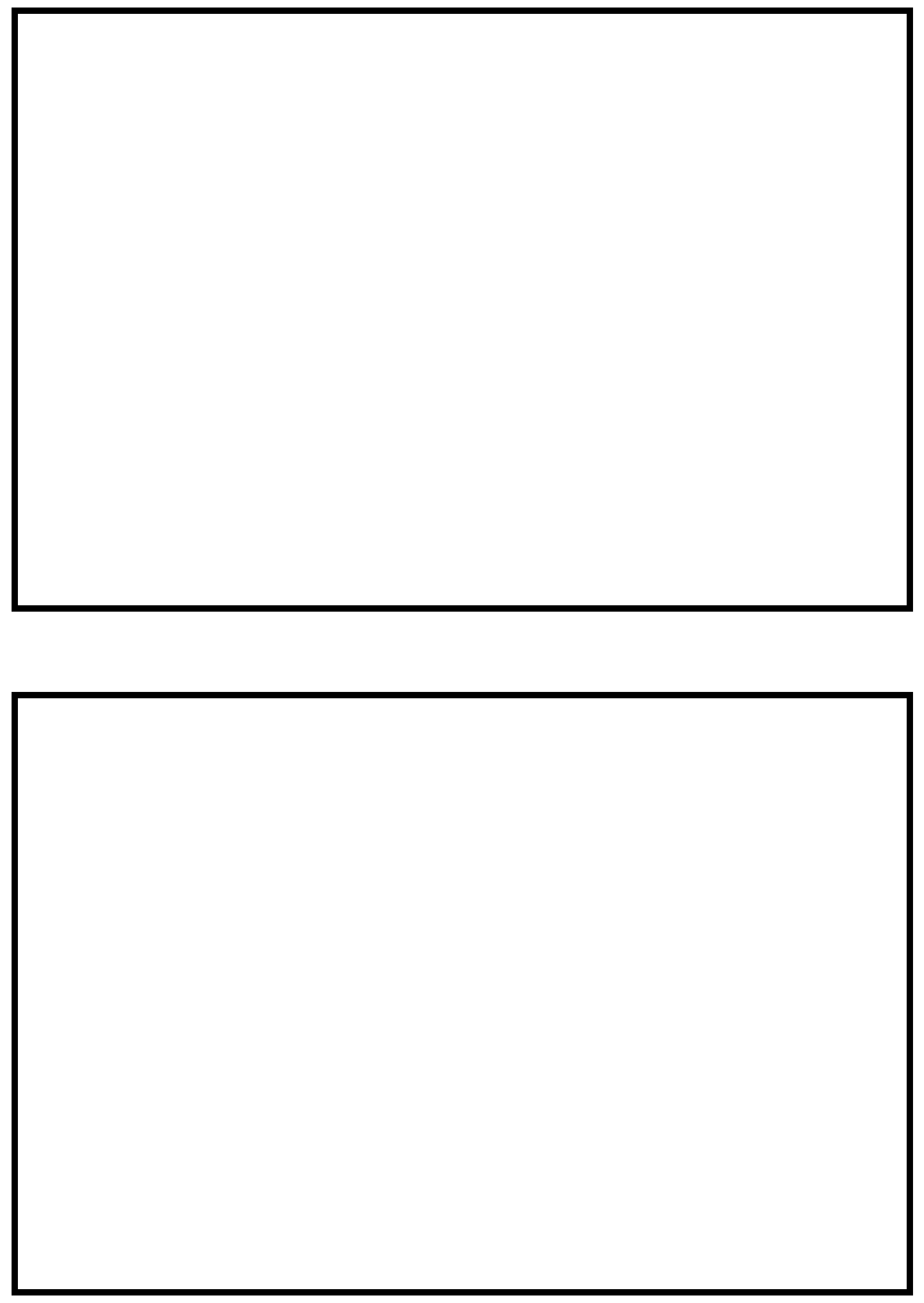

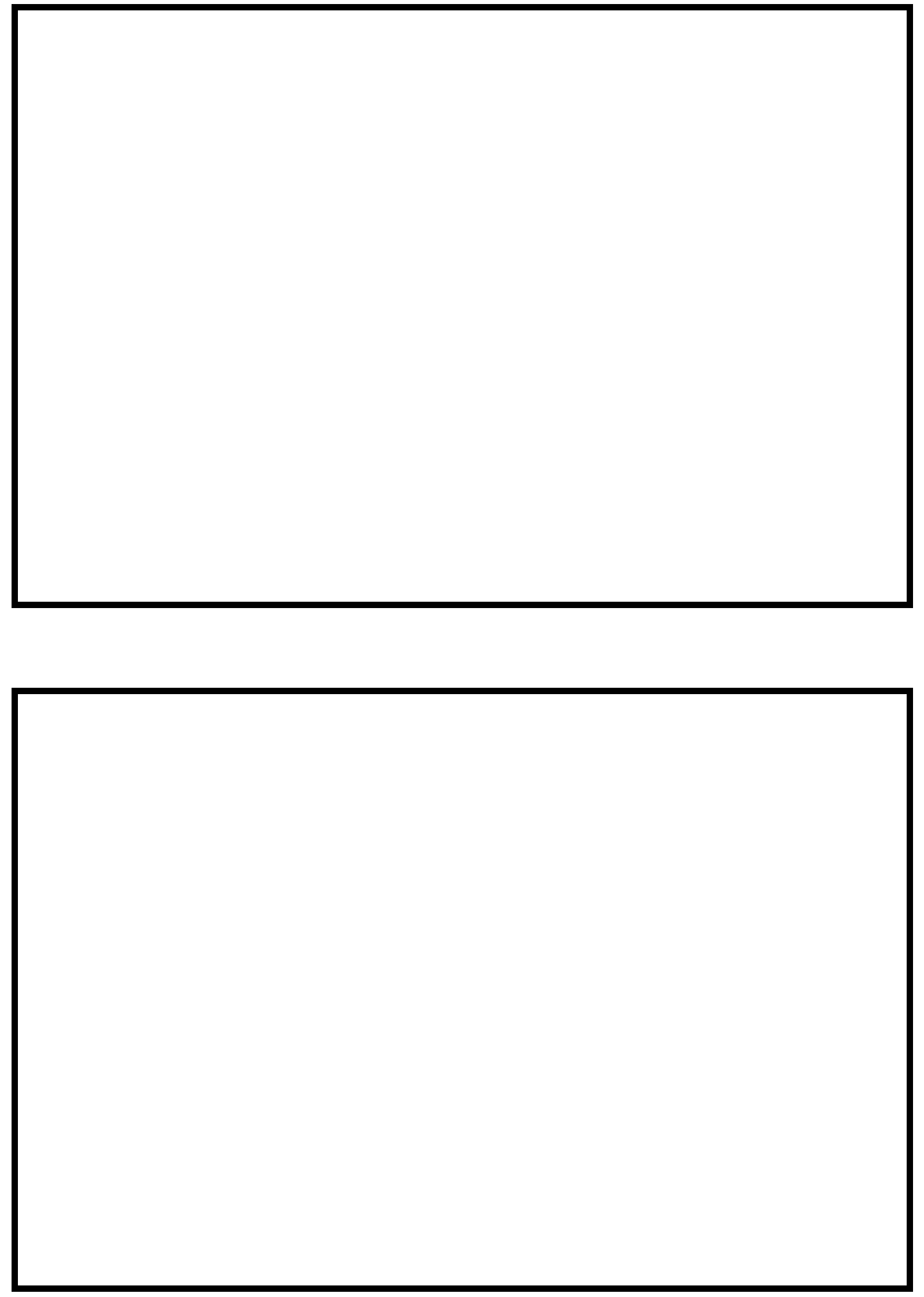


\section{LEVEL II SUMMARY}

\begin{tabular}{llllll} 
Structure Number & FERDVT01050094 & \multirow{2}{*}{ Stream } & \multicolumn{3}{l}{ Nulhegan River } \\
& Essex & Road & VT 105 & District & 9
\end{tabular}

\section{Description of Bridge}

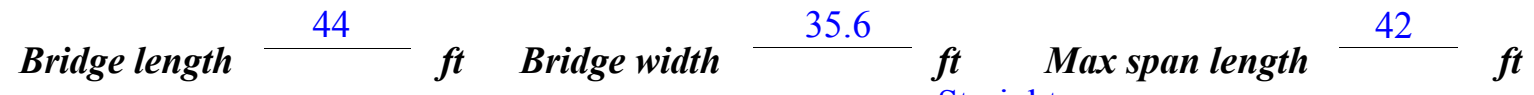
Alignment of bridge to road (on curve or straight)

Abutment type $\begin{gathered}\text { Vertical, concrete } \\ \text { Yes }\end{gathered}$ Embankment type $\frac{\text { Sloping }}{7 / 5 / 95}$

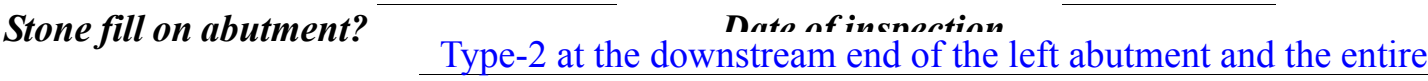
length of the right abutment. Type-2 stone fill also is present on the upstream right bank and right wingwall, and the downstream wingwalls.

Abutments and wingwalls are concrete. The abutment

walls silope slightly at an angle closer to 85 degrees than vertical.

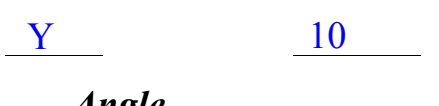

Is bridge skewed to flood flow according to Y ' survey? Angle

There is a moderate channel bend in the upstream reach. The right bank at the bend is protected but the stone fill has slumped.

Debris accumulation on bridge at time of Level I or Level II site visit:

\begin{tabular}{|c|c|c|}
\hline $\begin{array}{c}\text { Date of insnortion } \\
7 / 5 / 95 \\
\end{array}$ & $\begin{array}{l}\text { Percent of alomnal } \\
\text { blocked inorizontatly }\end{array}$ & $\begin{array}{l}\text { Percent of all wel } \\
\text { blocked verticatty }\end{array}$ \\
\hline & 0 & 0 \\
\hline
\end{tabular}

Level II Moderate. While there are young trees and shrubs on the banks, the channel reach is meandering and laterally unstable.

Potential for debris

None evident on 7/5/95.

Dosrriho anv, fonturos noar ar at tho hridoo that mav, affort flow (includo ahsorvation dato) 


\section{Description of the Geomorphic Setting}

General topography The channel is located in a moderate relief valley setting with wide, irregular flood plains and moderately sloping valley walls.

Geomorphic conditions at bridge site: downstream (DS), upstream (US)

Date of inspection $\quad 7 / 5 / 95$

DS left: $\quad$ Gradually sloping channel bank to flood plain.

DS right: $\quad$ Moderately sloping channel bank to flood plain.

US left: $\quad$ Gradually sloping channel bank to flood plain.

US right: $\quad$ Moderately sloping channel bank to flood plain.

\section{Description of the Channel}

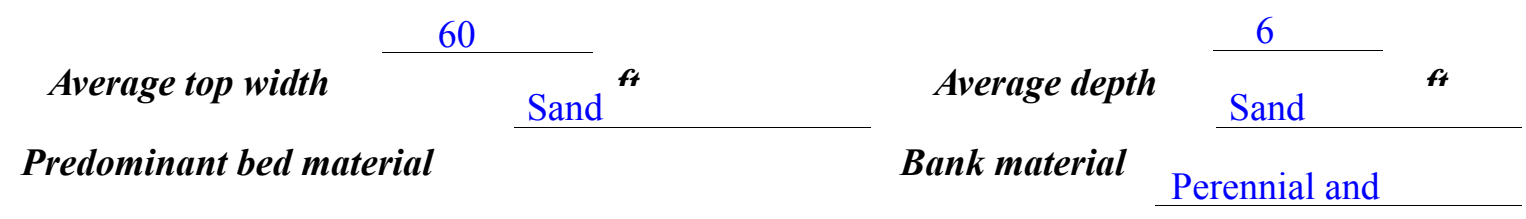

meandering through wetland with alluvial channel boundaries.

$\begin{array}{llllll}7 / 5 / 95 \\ \text { Vegetative co } \text { Trees and shrubs. } & \cdots & - & \ldots & .\end{array}$

DS left: $\quad$ Shrubs and brush.

DS right: $\quad$ Shrubs and brush.

US left: $\quad$ Shrubs and brush.

US right: $\quad \underline{\mathrm{N}}$

Do banks appear stable? There are many channel bends in the reach near this bridge with cut-

bank development. Blocks of bank material were noted as having slumped away from the rest of
date of observatton. the material. Point bars also were generally coincident on the opposite bank from the cut-banks.

None evident on

$7 / 5 / 95$.

Describe any obstructions in channel and date of observation. 


\title{
Hydrology
}

Drainage area $\quad 38.4 \boldsymbol{m i}^{2}$

Percentage of drainage area in physiographic provinces: (approximate)

Physiographic province/section

New England / White Mountain
Percent of drainage area 100

\begin{abstract}
Is drainage area considered rural or urban? Rural Describe any significant
urbanization: None.
\end{abstract}

Is there a USGS gage on the stream of interest?

No

USGS gage description

USGS gage number

Gage drainage area $\mathrm{mi}^{2}$ $m i^{2}$ No

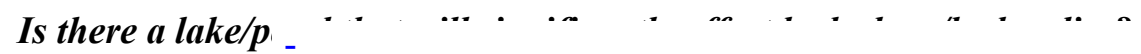

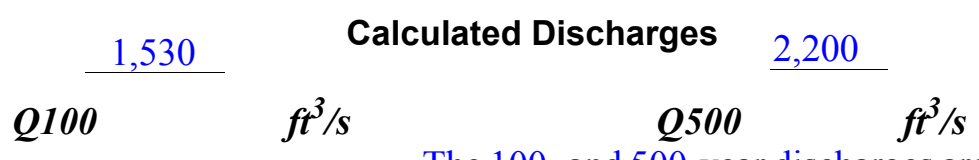

The 100- and 500-year discharges are based on flood

frequency estimates computed by use of several empirical relationships (Benson, 1962; Johnson and Tasker, 1974; FHWA, 1983; Potter, 1957; Talbot, 1887) and those available from the VTAOT database (written communication, May, 1995). Due to the central tendency of the flood frequency curve with the others, the discharges from the Benson (1962) relationship were selected. 


\section{Description of the Water-Surface Profile Model (WSPRO) Analysis}

Datum for WSPRO analysis (USGS survey, sea level, VTAOT plans)

USGS survey

Datum tie between USGS survey and VTAOT plans

Add 152.15 feet to USGS survey

to obtain VTAOT plans' datum and NGVD.

Description of reference marks used to determine USGS datum. $\quad$ RM2 is the center point

of a chisled "X" on top of the concrete curb at the downstream right corner of the bridge deck

(elev. $999.95 \mathrm{ft}$, arbitrary survey datum). RM3 is the center of an engraved triangle in a VTAOT

survey mark, brass tablet on top of the upstream end of the left abutment (elev. $1000.08 \mathrm{ft}$,

arbitrary survey datum).

\section{Cross-Sections Used in WSPRO Analysis}

\begin{tabular}{|c|c|c|c|}
\hline${ }^{1}$ Cross-section & $\begin{array}{c}\text { Section } \\
\text { Reference } \\
\text { Distance } \\
\text { (SRD) in feet }\end{array}$ & $\begin{array}{c}{ }^{2} \text { Cross-section } \\
\text { development }\end{array}$ & Comments \\
\hline EXITX & -48 & 1 & Exit section \\
\hline FULLV & 0 & 2 & $\begin{array}{l}\text { Downstream Full-valley } \\
\text { section (Templated from } \\
\text { EXITX) }\end{array}$ \\
\hline BRIDG & 0 & 1 & Bridge section \\
\hline RDWAY & 20 & 1 & Road Grade section \\
\hline APPRO & 79 & 1 & Approach section \\
\hline
\end{tabular}

${ }^{1}$ For location of cross-sections see plan-view sketch included with Level I field form, Appendix E. For more detail on how cross-sections were developed see WSPRO input file. 


\section{Data and Assumptions Used in WSPRO Model}

Hydraulic analyses of the reach were done by use of the Federal Highway Administration's WSPRO step-backwater computer program (Shearman and others, 1986, and Shearman, 1990). The analyses reported herein reflect conditions existing at the site at the time of the study. Furthermore, in the development of the model it was necessary to assume no accumulation of debris or ice at the site. Results of the hydraulic model are presented in the Bridge Hydraulic Summary, Appendix B, and figure 7.

Channel roughness factors (Manning's " $n$ ") used in the hydraulic model were estimated using field inspections at each cross section following the general guidelines described by Arcement and Schneider (1989). Final adjustments to the values were made during the modelling of the reach. Channel " $n$ " values for the reach ranged from 0.030 to 0.035 , and overbank " $\mathrm{n}$ " values ranged from 0.045 to 0.065 .

Although the North Branch of the Nulhegan River enters the main stem about 70 feet downstream of this site, the differences in watershed area and characteristics suggest that the peak discharges on each reach are not contemporaneous. Therefore, no backwater effects were assumed and normal depth at the exit section (EXITX) was assumed as the starting water surface. This depth was computed by use of the slope-conveyance method outlined in the user's

manual for WSPRO (Shearman, 1990). The slope used was $0.0016 \mathrm{ft} / \mathrm{ft}$ which was estimated from the topographic map over one contour interval downstream of the site (U.S. Geological Survey, 1988).

The approach section (APPRO) was surveyed at one bridge length upstream of the upstream face as recommended by Shearman and others (1986). This method also provides a consistent method for determining scour variables. 


\section{Bridge Hydraulics Summary}

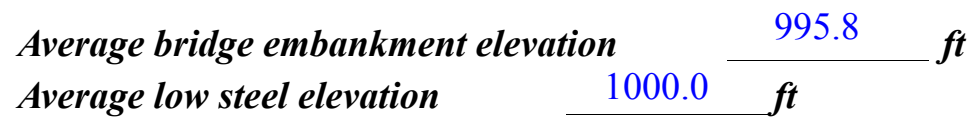

100-year discharge $\quad 1,530 \quad \mathrm{ft}^{3} / \mathrm{s}$

Water-surface elevation in bridge opening $\quad 991.3 \quad f t$

Road overtopping? ___ No Discharge over road __ ${ }^{--}, \ldots$

\begin{tabular}{llcc} 
Area of flow in bridge opening & 185 & $\boldsymbol{f t}^{2}$ \\
\cline { 2 - 3 } Average velocity in bridge opening & 8.3 & $\boldsymbol{f t} / \mathrm{s}$
\end{tabular}

Maximum WSPRO tube velocity at bridge $\quad \begin{array}{lll}9.8 & \mathrm{t} / \mathrm{s}\end{array}$

Water-surface elevation at Approach section with bridge 992.1

Water-surface elevation at Approach section without bridge $\quad \overline{99} 1.8$

Amount of backwater caused by bridge

0.3 it

500-year discharge $\quad 2,200 \quad \mathrm{ft}^{3} / \mathrm{s}$

Water-surface elevation in bridge opening

$992.4 \boldsymbol{f t}$

Road overtopping? ___ No Discharge over road ___ -- $\quad r^{3} / \mathrm{s}$

Area of flow in bridge opening _ $\quad 226 \quad \mathrm{ft}^{2}$

Average velocity in bridge opening $\quad 9.7 \mathrm{ft} / \mathrm{s}$

Maximum WSPRO tube velocity at bridge 11.4 's

Water-surface elevation at Approach section with bridge 993.6

Water-surface elevation at Approach section without bridge

Amount of backwater caused by bridge 0.5 .

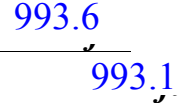

Incipient overtopping discharge ___ -- $\mathrm{ft}^{3} / \mathrm{s}$

Water-surface elevation in bridge opening $\quad--\quad t$

Area of flow in bridge opening _ $\quad--\quad \mathrm{ft}^{2}$

Average velocity in bridge opening __- $\quad \mathrm{ft} / \mathrm{s}$

Maximum WSPRO tube velocity at bridge _-- $\mathrm{ft} / \mathrm{s}$

Water-surface elevation at Approach section with bridge

Water-surface elevation at Approach section without bridge

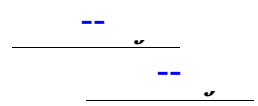

Amount of backwater caused by bridge _ 


\section{Scour Analysis Summary}

\section{Special Conditions or Assumptions Made in Scour Analysis}

Scour depths were computed using the general guidelines described in Hydraulic Engineering Circular 18 (Richardson and others, 1995). Scour depths were calculated assuming an infinite depth of erosive material and a homogeneous particle-size distribution. The results of the scour analysis are presented in tables 1 and 2 and a graph of the scour depths is presented in figure 8.

Contraction scour was computed by use of the live-bed contraction scour equation (Richardson and others, 1995, p. 30, equations 17 and 18). For contraction scour computations, the average depth in the contracted section (AREA/TOPWIDTH) is subtracted from the depth of flow computed by the scour equation (Y2) to determine the actual amount of scour. In this case, the 500-year discharge resulted in the worst case contraction scour.

Abutment scour was computed by use of the Froehlich equation (Richardson and others, 1995, p. 48, equation 28). Variables for the Froehlich equation include the Froude number of the flow approaching the embankments, the length of the embankment blocking flow, and the depth of flow approaching the embankment less any roadway overtopping. 


\title{
Scour Results
}

100-yr discharge 500-yr discharge

Incipient

Contraction scour:

(Scour depths in feet)

Main channel

$$
\begin{aligned}
& \text { Live-bed scour } \\
& \text { Clear-water scour } \\
& \text { Depth to armoring }
\end{aligned}
$$

Left overbank

Right overbank

Local scour:

Abutment scour

Left abutment

Right abutment

Pier scour

Pier 1

Pier 2

Pier 3

Abutments:

Left abutment

Right abutment

Piers:

Pier 1

Pier 2

overtopping discharge

\author{
(Scour depths in feet)
}
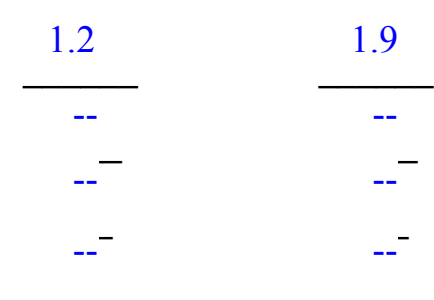

$--$

$-$

$--$

--

$--$
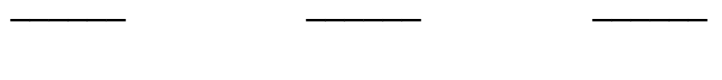

\section{Riprap Sizing}

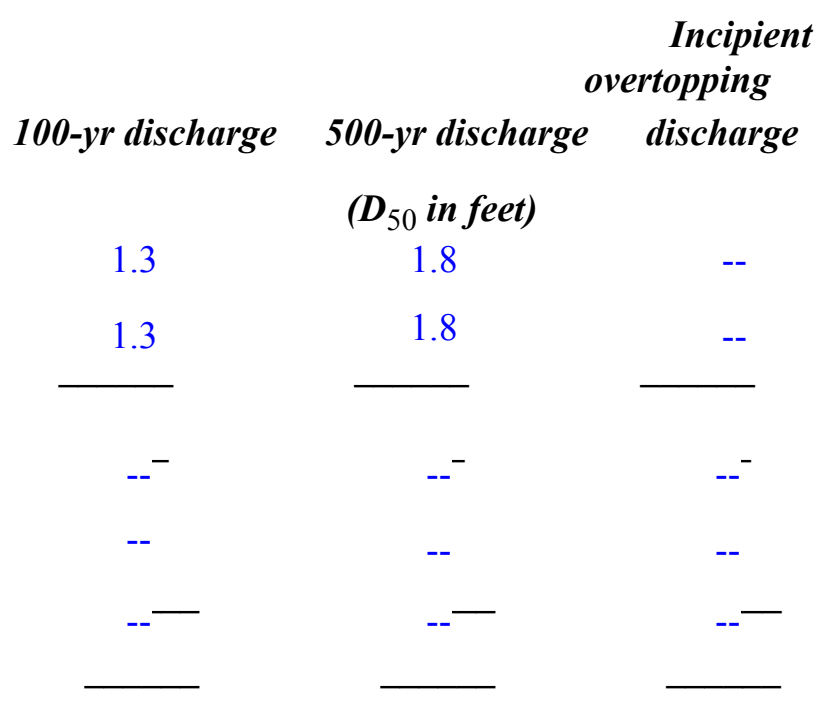




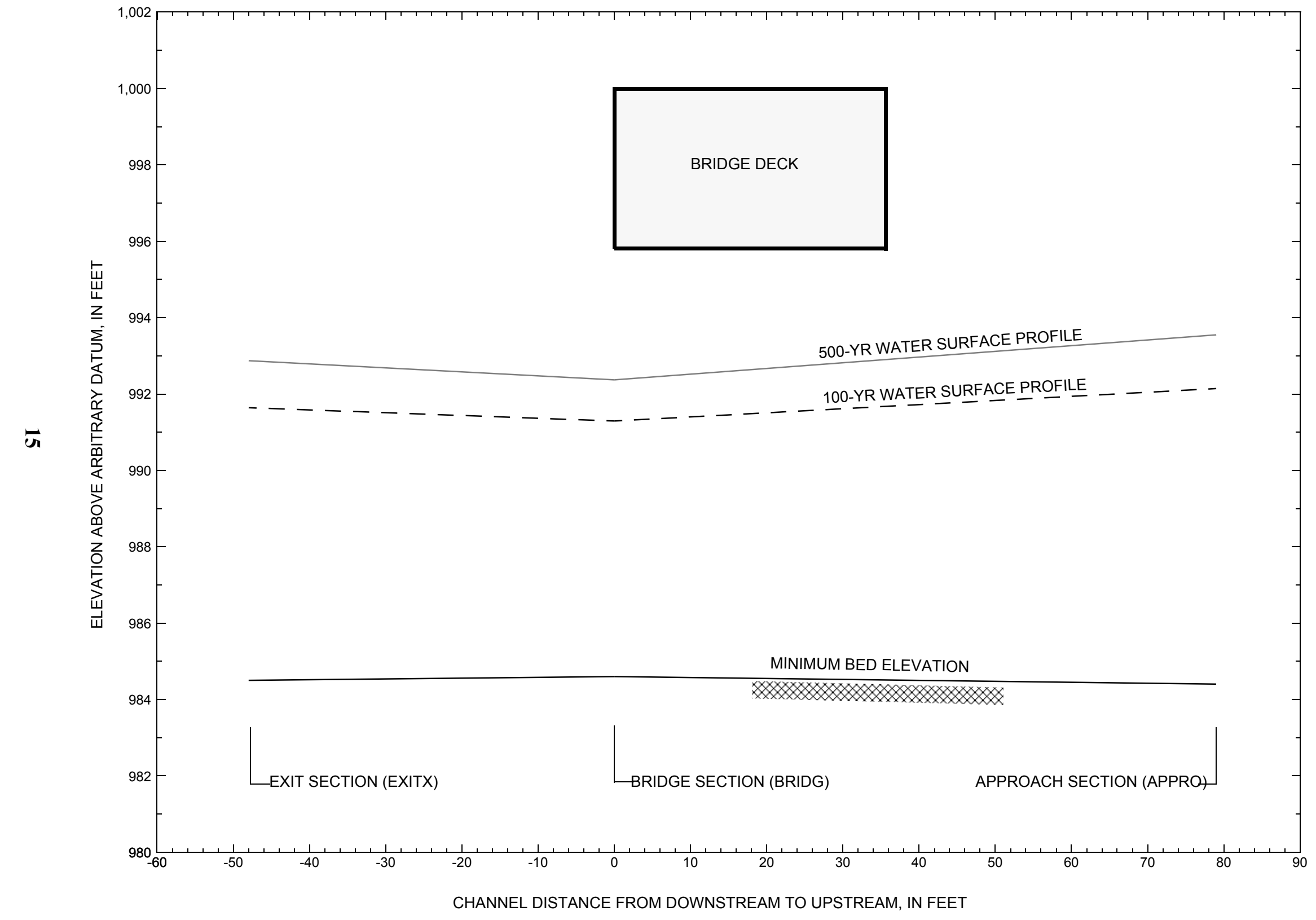

Figure 7. Water-surface profiles for the 100- and 500-yr discharges at structure FERDVT01050094 on State Route 105, crossing the Nulhegan River, Ferdinand, Vermont. 


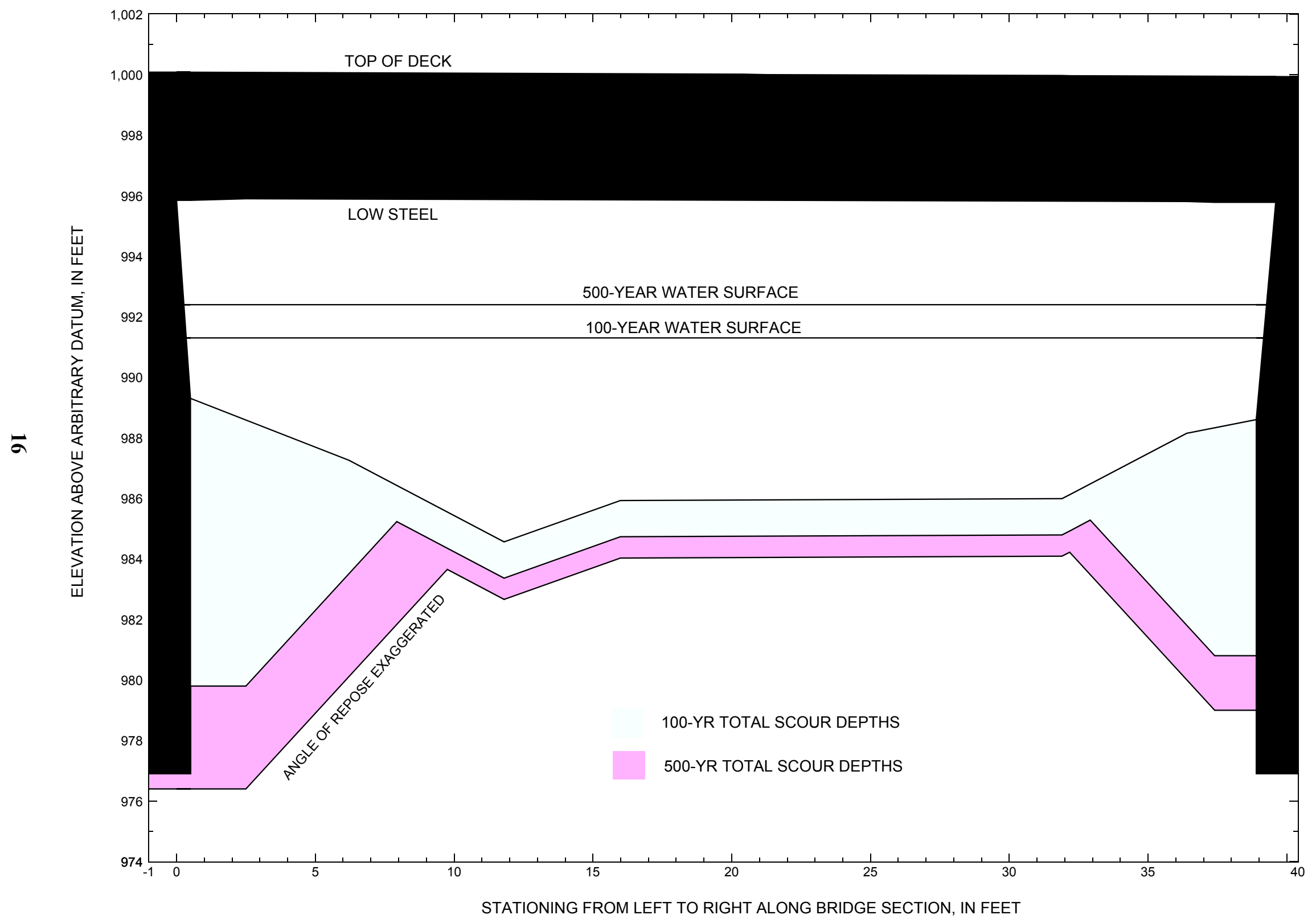

Figure 8. Scour elevations for the 100-yr and 500-yr discharges at structure FERDVT01050094 on State Route 105, crossing the Nulhegan River, Ferdinand, Vermont. 
Table 1. Remaining footing/pile depth at abutments for the 100-year discharge at structure FERDVT01050094 on State Route 105, crossing the Nulhegan River, Ferdinand, Vermont.

[VTAOT, Vermont Agency of Transportation; --,no data]

\begin{tabular}{|c|c|c|c|c|c|c|c|c|c|c|c|}
\hline Description & Station $^{1}$ & $\begin{array}{l}\text { VTAOT } \\
\text { bridge seat } \\
\text { elevation } \\
\text { (feet) }\end{array}$ & $\begin{array}{l}\text { Surveyed } \\
\text { minimum } \\
\text { low-chord } \\
\text { elevation }{ }^{2} \\
\text { (feet) }\end{array}$ & $\begin{array}{c}\text { Bottom of } \\
\text { footing } \\
\text { elevation } \\
\text { (feet) }\end{array}$ & $\begin{array}{l}\text { Channel } \\
\text { elevation at } \\
\text { abutment/ } \\
\text { pier }^{2} \\
\text { (feet) }\end{array}$ & $\begin{array}{l}\text { Contraction } \\
\text { scour depth } \\
\text { (feet) }\end{array}$ & $\begin{array}{l}\text { Abutment } \\
\text { scour } \\
\text { depth } \\
\text { (feet) }\end{array}$ & $\begin{array}{l}\text { Pier } \\
\text { scour } \\
\text { depth } \\
\text { (feet) }\end{array}$ & $\begin{array}{l}\text { Depth of } \\
\text { total scour } \\
\text { (feet) }\end{array}$ & $\begin{array}{c}\text { Elevation of } \\
\text { scour }^{2} \\
\text { (feet) }\end{array}$ & $\begin{array}{c}\text { Remaining } \\
\text { footing/pile } \\
\text { depth } \\
\text { (feet) }\end{array}$ \\
\hline \multicolumn{12}{|c|}{100 -yr. discharge is 1,530 cubic-feet per second } \\
\hline Left abutment & 0.5 & 1144.3 & 995.9 & 976.9 & 989.3 & 1.2 & 8.3 & -- & 9.5 & 979.8 & 2.9 \\
\hline Right abutment & 38.9 & 1145.0 & 995.8 & 976.9 & 988.6 & 1.2 & 6.6 & -- & 7.8 & 980.8 & 3.9 \\
\hline
\end{tabular}

1.Measured along the face of the most constricting side of the bridge.

2.Arbitrary datum for this study.

Table 2. Remaining footing/pile depth at abutments for the 500-year discharge at structure FERDVT01050094 on State Route 105, crossing the Nulhegan River, Ferdinand, Vermont.

[VTAOT, Vermont Agency of Transportation; --, no data]

\begin{tabular}{|c|c|c|c|c|c|c|c|c|c|c|c|}
\hline Description & Station $^{1}$ & $\begin{array}{l}\text { VTAOT } \\
\text { bridge seat } \\
\text { elevation } \\
\text { (feet) }\end{array}$ & $\begin{array}{c}\text { Surveyed } \\
\text { minimum } \\
\text { low-chord } \\
\text { elevation }{ }^{2} \\
\text { (feet) }\end{array}$ & $\begin{array}{c}\text { Bottom of } \\
\text { footing } \\
\text { elevation } \\
\text { (feet) }\end{array}$ & $\begin{array}{c}\text { Channel } \\
\text { elevation at } \\
\text { abutment/ } \\
\text { pier }^{2} \\
\text { (feet) }\end{array}$ & $\begin{array}{l}\text { Contraction } \\
\text { scour depth } \\
\text { (feet) }\end{array}$ & $\begin{array}{l}\text { Abutment } \\
\text { scour } \\
\text { depth } \\
\text { (feet) }\end{array}$ & $\begin{array}{l}\text { Pier } \\
\text { scour } \\
\text { depth } \\
\text { (feet) }\end{array}$ & $\begin{array}{l}\text { Depth of } \\
\text { total scour } \\
\text { (feet) }\end{array}$ & $\begin{array}{c}\text { Elevation of } \\
\text { scour }^{2} \\
\text { (feet) }\end{array}$ & $\begin{array}{c}\text { Remaining } \\
\text { footing/pile } \\
\text { depth } \\
\text { (feet) }\end{array}$ \\
\hline \multicolumn{12}{|c|}{500 -yr. discharge is 2,200 cubic-feet per second } \\
\hline Left abutment & 0.5 & 1144.3 & 995.9 & 976.9 & 989.3 & 1.9 & 11.0 & -- & 12.9 & 976.4 & -0.5 \\
\hline Right abutment & 38.9 & 1145.0 & 995.8 & 976.9 & 988.6 & 1.9 & 7.7 & -- & 9.6 & 979.0 & 2.1 \\
\hline
\end{tabular}

1.Measured along the face of the most constricting side of the bridge.

2.Arbitrary datum for this study. 


\section{SELECTED REFERENCES}

Arcement, G.J., Jr., and Schneider, V.R., 1989, Guide for selecting Manning's roughness coefficients for natural channels and flood plains: U.S. Geological Survey Water-Supply Paper 2339, 38 p.

Barnes, H.H., Jr., 1967, Roughness characteristics of natural channels: U.S. Geological Survey Water-Supply Paper 1849,213 p.

Benson, M. A., 1962, Factors Influencing the Occurrence of Floods in a Humid Region of Diverse Terrain: U.S. Geological Survey WaterSupply Paper 1580-B, 64 p.

Brown, S.A. and Clyde, E.S., 1989, Design of riprap revetment: Federal Highway Administration Hydraulic Engineering Circular No. 11, Publication FHWA-IP-89-016, 156 p.

Federal Highway Administration, 1983, Runoff estimates for small watersheds and development of sound design: Federal Highway Administration Report FHWA-RD-77-158

Froehlich, D.C., 1989, Local scour at bridge abutments in Ports, M.A., ed., Hydraulic Engineering--Proceedings of the 1989 National Conference on Hydraulic Engineering: New York, American Society of Civil Engineers, p. 13-18.

Hayes, D.C.,1993, Site selection and collection of bridge-scour data in Delaware, Maryland, and Virginia: U.S. Geological Survey WaterResources Investigation Report 93-4017, 23 p.

Johnson, C.G. and Tasker, G.D.,1974, Progress report on flood magnitude and frequency of Vermont streams: U.S. Geological Survey OpenFile Report 74-130, 37 p.

Lagasse, P.F., Schall, J.D., Johnson, F., Richardson, E.V., Chang, F., 1995, Stream Stability at Highway Structures: Federal Highway Administration Hydraulic Engineering Circular No. 20, Publication FHWA-IP-90-014, 144 p.

Laursen, E.M., 1960, Scour at bridge crossings: Journal of the Hydraulics Division, American Society of Civil Engineers, v. 86, no. HY2, p. 39-53.

Potter, W. D., 1957, Peak rates of runoff in the Adirondack, White Mountains, and Maine woods area, Bureau of Public Roads

Richardson, E.V. and Davis, S.R., 1995, Evaluating scour at bridges: Federal Highway Administration Hydraulic Engineering Circular No. 18, Publication FHWA-IP-90-017, 204 p.

Richardson, E.V., Simons, D.B., and Julien, P.Y., 1990, Highways in the river environment: Federal Highway Administration Publication FHWA-HI-90-016.

Ritter, D.F., 1984, Process Geomorphology: W.C. Brown Co., Debuque, Iowa, 603 p.

Shearman, J.O., 1990, User's manual for WSPRO--a computer model for water surface profile computations: Federal Highway Administration Publication FHWA-IP-89-027, 187 p.

Shearman, J.O., Kirby, W.H., Schneider, V.R., and Flippo, H.N., 1986, Bridge waterways analysis model; research report: Federal Highway Administration Publication FHWA-RD-86-108, 112 p.

Talbot, A.N., 1887, The determination of water-way for bridges and culverts.

U.S. Department of Transportation, 1993, Stream stability and scour at highway bridges, Participant Workbook: Federal Highway Administration Publication FHWA HI-91-011.

U.S. Geological Survey, 1988, Bloomfield, Vermont 7.5 Minute Series quadrangle map: U.S. Geological Survey Topographic Maps, Aerial photographs, 1983, Contour interval, 20 feet, Scale 1:24,000. 


\section{APPENDIX A: \\ WSPRO INPUT FILE}


WSPRO INPUT FILE (continued)

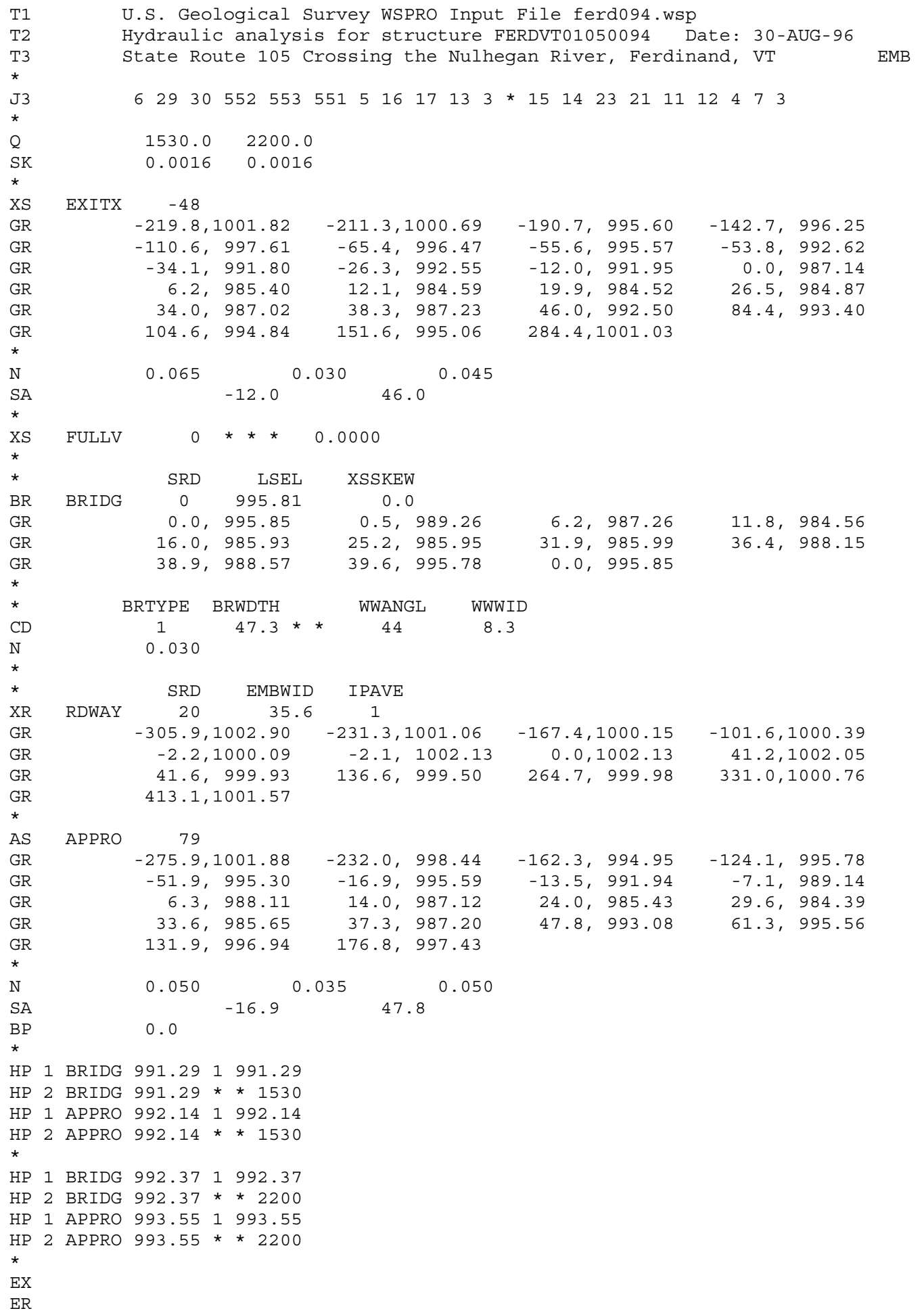




\section{APPENDIX B: \\ WSPRO OUTPUT FILE}


WSPRO OUTPUT FILE

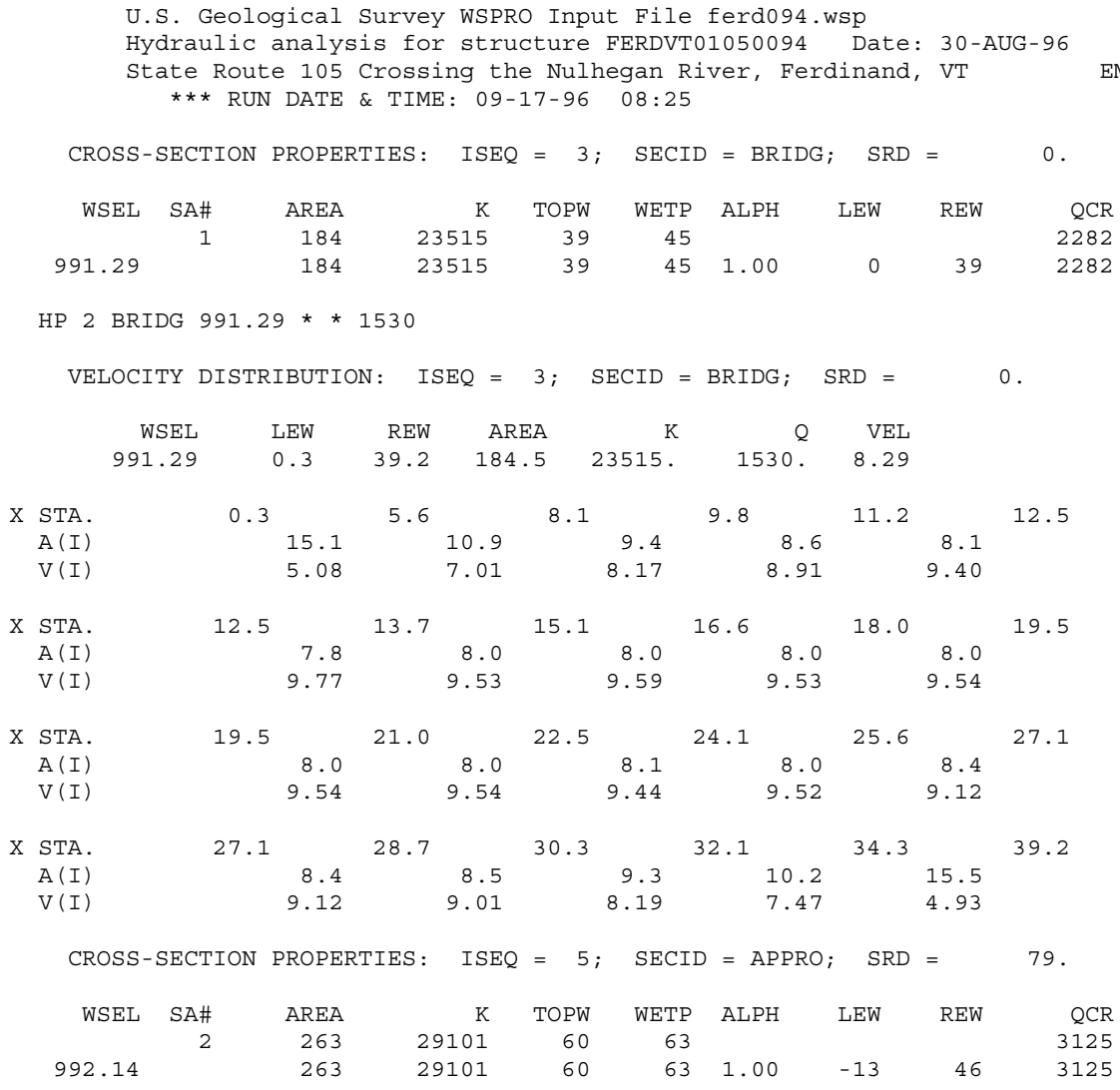

HP 2 APPRO 992.14* * 1530

VELOCITY DISTRIBUTION : ISEQ $=5 ; \quad$ SECID $=$ APPRO; $\quad$ SRD $=79$.

$\begin{array}{rrrrrrr}\text { WSEL } & \text { LEW } & \text { REW } & \text { AREA } & \text { K } & \text { Q } & \text { VEL } \\ 992.14 & -13.7 & 46.1 & 262.8 & 29101 . & 1530 . & 5.82\end{array}$

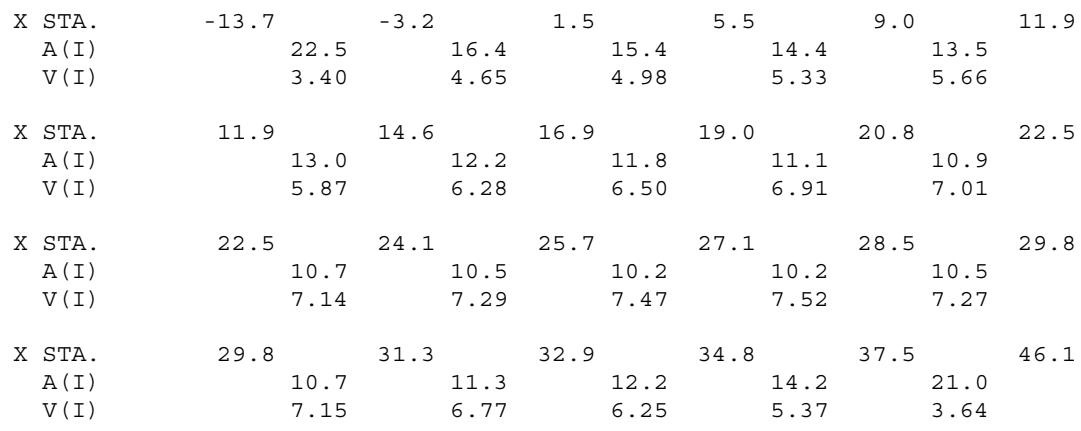

HP 1 BRIDG $992.37 \quad 1 \quad 992.37$ 
WSPRO OUTPUT FILE (continued)

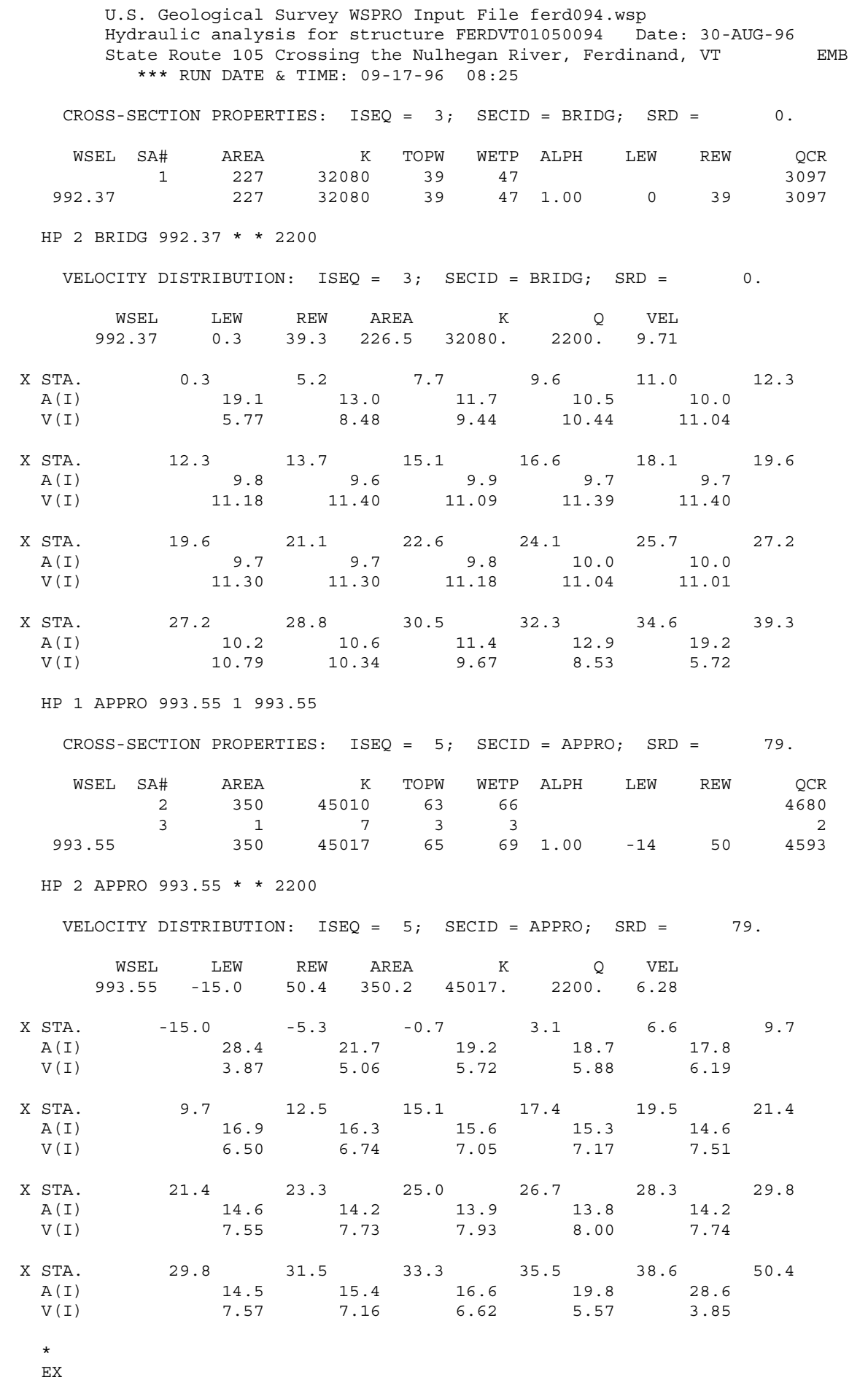


WSPRO OUTPUT FILE (continued)

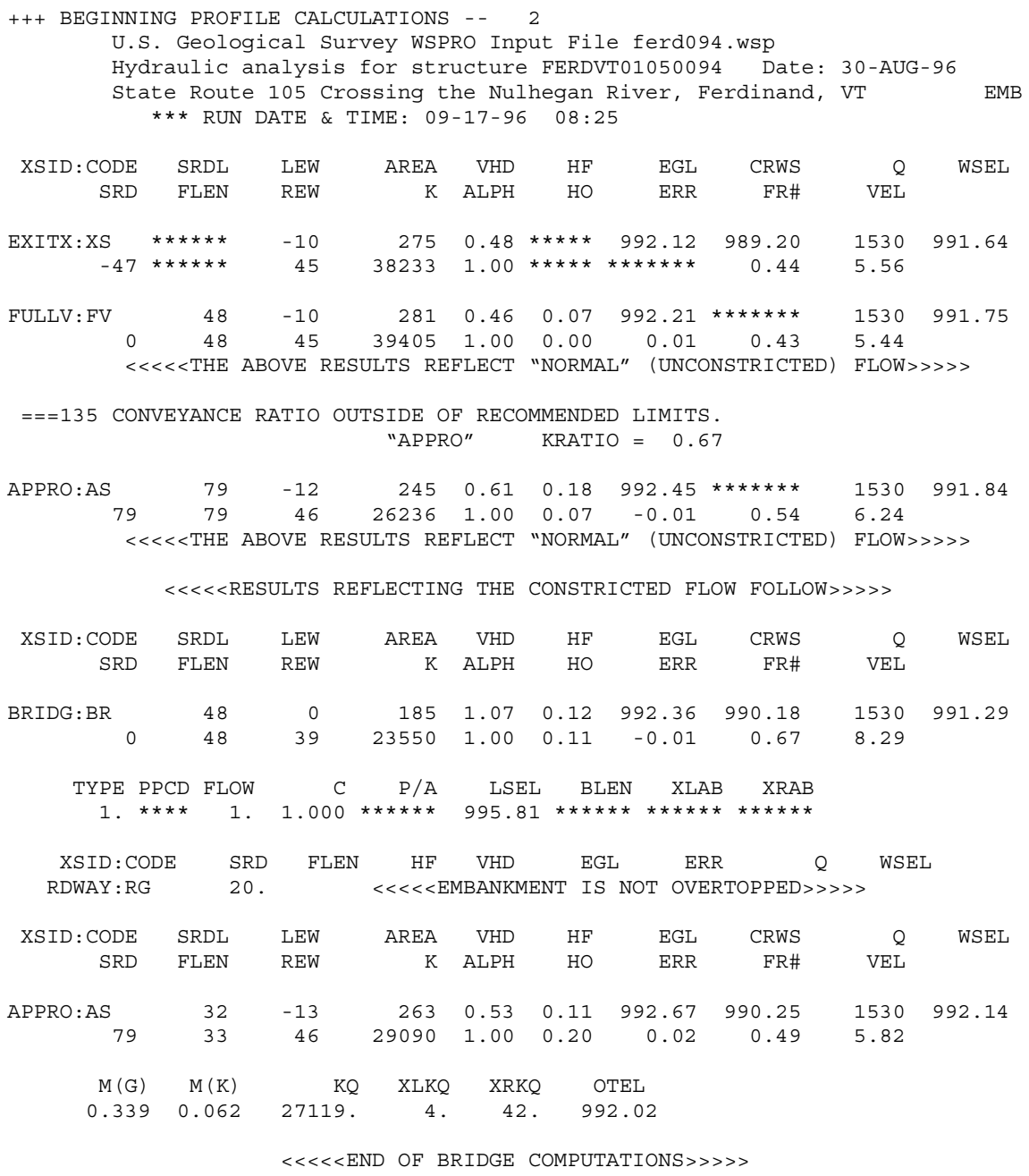


WSPRO OUTPUT FILE (continued)

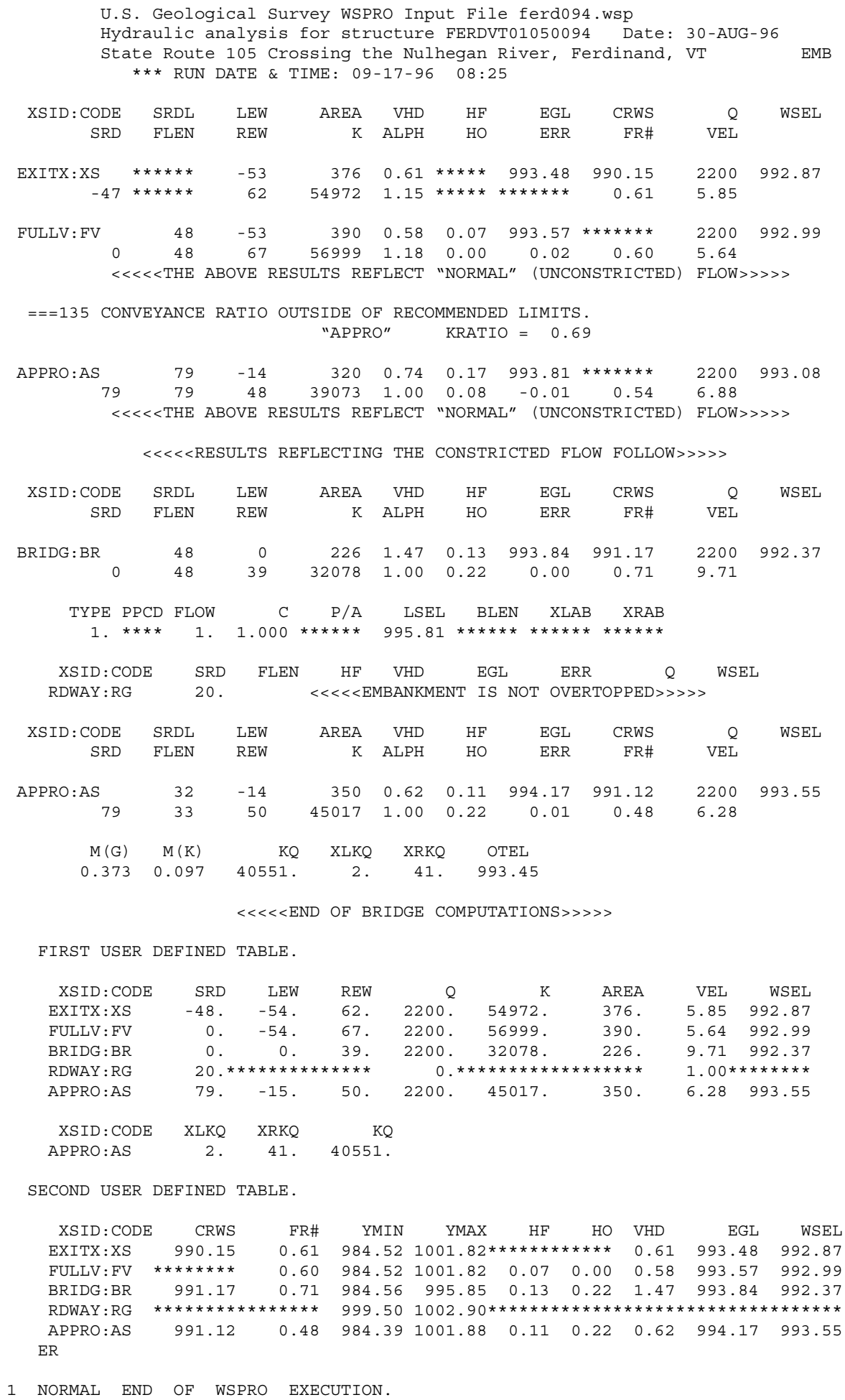




\section{APPENDIX C:}

\section{BED-MATERIAL PARTICAL-SIZE DISTRIBUTION}




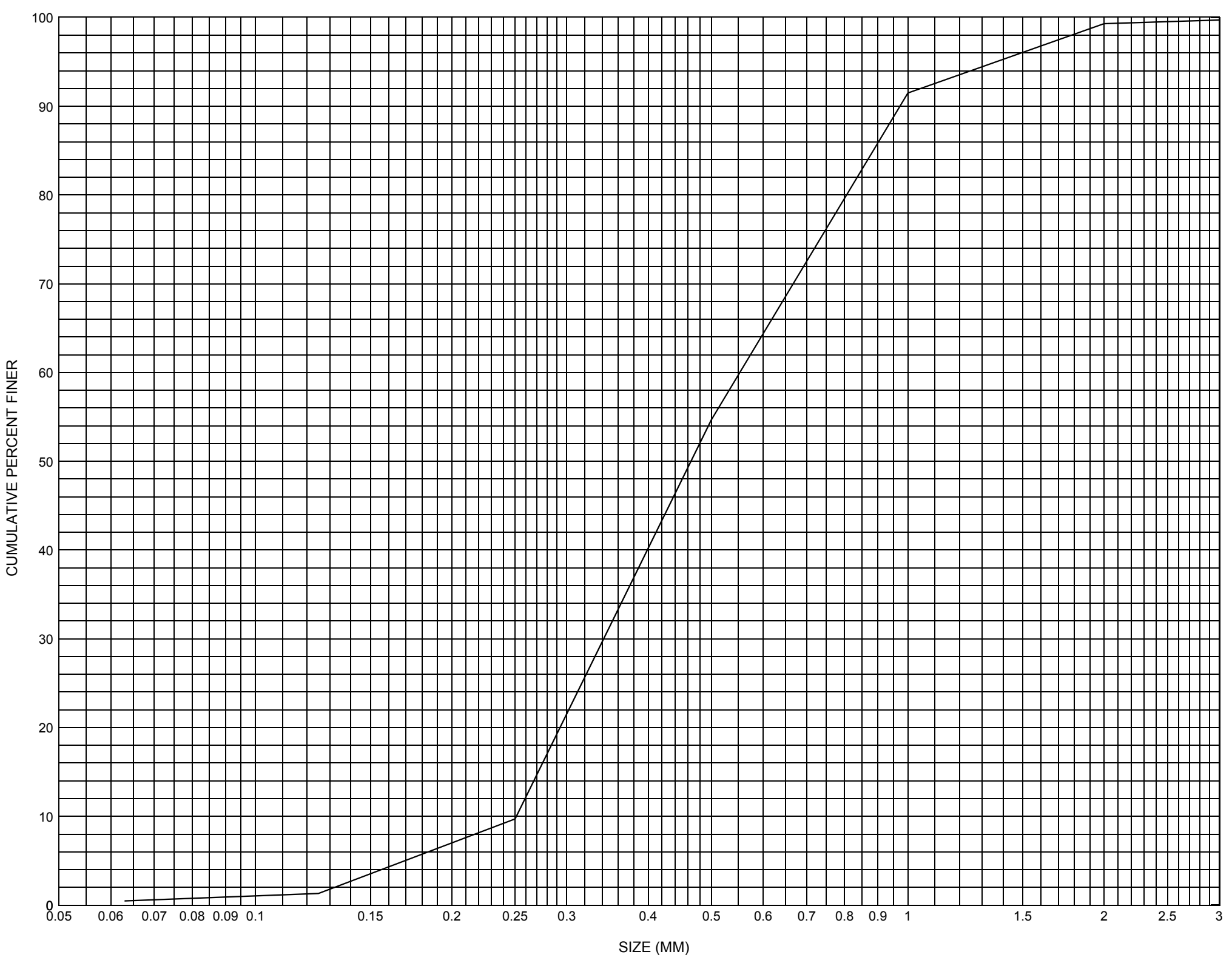

Appendix C. Bed material particle-size distribution for one channel composite sample at the approach section of structure FERDVT01050094, in Ferdinand, Vermont. 


\section{APPENDIX D: \\ HISTORICAL DATA FORM}




\section{Structure Number FERDVT01050094}

\section{General Location Descriptive}

Data collected by (First Initial, Full last name) $\underline{\text { L }}$. MEDALIE

Date $(M M / D D / Y Y) \_\mathbf{0 3} / \underline{06} / \underline{95}$

Highway District Number (I - 2; nn) $\mathbf{0 9}$

Town (FIPS place code; I - 4; nnnnn) $\mathbf{2 5 9 7 5}$

Waterway ( $I$ - 6) NULHEGAN RIVER

Route Number VT105

Topographic Map Bloomfield

Latitude (I - 16; nnnn.n) 44468
County (FIPS county code; I - 3; nnn)

Mile marker (I - 11; nnn.nnn) $\mathbf{0 0 3 3 4 0}$

Road Name (I - 7): -

Vicinity (I - 9) 7.6 MI W JCT. VT.102

Hydrologic Unit Code: $\mathbf{0 1 0 8 0 1 0 1}$

Longitude (i - 17; nnnnn.n) $\mathbf{7 1 4 4 4}$

\section{Select Federal Inventory Codes}

FHWA Structure Number $(I$ - 8) $\mathbf{2 0 0 0 3 4 0 0 9 4 0 5 0 9}$

Maintenance responsibility $(I-21 ; n n) \_$01_ Maximum span length $(I-48 ; n n n n) \underline{\mathbf{0 0 4 2}}$

Year built (I - 27; YYYY) 1979

Structure length (I - 49; nnnnnn) $\underline{000044}$

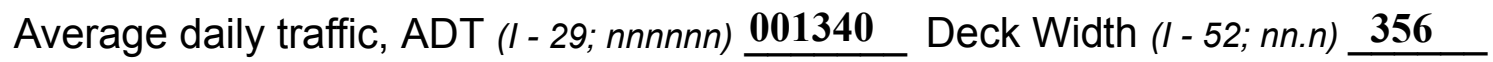

Year of ADT (I - 30; YY) $\mathbf{9 2}$

Channel \& Protection $(I-61 ; n) \underline{\mathbf{8}}$

Opening skew to Roadway $(I-34 ; n n) \quad \mathbf{0 0}$

Waterway adequacy $(I-71 ; n)$

Operational status $(I-41 ; X) \quad \mathbf{A}$

Underwater Inspection Frequency $(I-92 B ; X Y Y) \_\mathbf{N}$

Structure type (I- 43; nnn) $\mathbf{3 0 2}$

Year Reconstructed (I - 106) $\mathbf{0 0 0 0}$

Approach span structure type (I - 44; nnn) $\mathbf{0 0 0}$ Clear span $(n n n . n f t)$

Number of spans (I - 45; nnn) $\mathbf{0 0 1}$

Vertical clearance from streambed (nnn.n ft) $\underline{\mathbf{1 0 . 0}}$

Number of approach spans (I - 46; nnnn) $\mathbf{0 0 0 0}$

Waterway of full opening $\left(n n n . n \mathrm{ft}^{2}\right)$

Comments:

The structural inspection report of 10/19/93 indicates the structure is a single span, steel stringer type bridge. The abutments are older concrete with newer concrete bearing caps and wingwalls. The older concrete has a couple of minor spalls noted. The waterway takes a slight to moderate turn through the structure. The banks and abutments are well protected with stone fill. The stream bed consists of sand and stone. The structure is in relatively good condition according to the report. No problems are noted for channel scour, bank erosion, or debris. 


\section{Bridge Hydrologic Data}

Is there hydrologic data available? $\underline{\mathbf{Y}}$ if No, type ctrl-n $h \quad$ VTAOT Drainage area $\left(m i^{2}\right): \underline{\mathbf{3 7 . 8}}$

Terrain character:

Stream character \& type: -

Streambed material: Sand and boulder with some silt

Discharge Data (cfs): $\quad \mathrm{Q}_{2.33}-$

$$
\mathrm{Q}_{50} \mathbf{1 2 0 0}
$$

Record flood date $(M M / D D / Y Y):-$

$\begin{array}{lll}Q_{10} \frac{650}{1450} & Q_{25} \frac{950}{-} \\ Q_{100} & Q_{500}-\end{array}$

Water surface elevation $(f t)$ : -

Estimated Discharge (cfs): _ _ Velocity at Q $\underline{\mathbf{5 0}}(\mathrm{ft} / \mathrm{s}): \underline{\mathbf{3}}$

Ice conditions (Heavy, Moderate, Light) : - _ Debris (Heavy, Moderate, Light): Light

The stage increases to maximum highwater elevation (Rapidly, Not rapidly): -

The stream response is (Flashy, Not flashy):

Describe any significant site conditions upstream or downstream that may influence the stream's stage: Marshy conditions, a slight meander, and beaver activity in the vicinity were noted.

Watershed storage area (in percent):

The watershed storage area is: - _ (1-mainly at the headwaters; 2- uniformly distributed; 3-immediatly upstream oi the site)

Water Surface Elevation Estimates for Existing Structure:

\begin{tabular}{|l|l|c|c|l|l|}
\hline Peak discharge frequency & $Q_{2.33}$ & $Q_{10}$ & $Q_{25}$ & $Q_{50}$ & $Q_{100}$ \\
Water surface elevation (ft)) & - & $\mathbf{1 1 3 9 . 2}$ & $\mathbf{1 1 4 0 . 9}$ & $\mathbf{1 1 4 2 . 3}$ & $\mathbf{1 1 4 3 . 2}$ \\
Velocity $(\mathrm{ft} / \mathrm{sec})$ & - & - & - & $\mathbf{3 . 0}$ & - \\
\hline
\end{tabular}

Long term stream bed changes: -

Is the roadway overtopped below the $\mathrm{Q}_{100}$ ? (Yes, No, Unknown): $\mathbf{U} \quad$ Frequency: -

Relief Elevation $(f t)$ :

Discharge over roadway at $\mathrm{Q}_{100}\left(\mathrm{ft}^{3} / \mathrm{sec}\right)$ :

Are there other structures nearby? (Yes, No, Unknown): $\mathbf{U}$ Upstream distance (miles): Town: If No or Unknown, type ctrl-n os Highway No. : Structure No. : Year Built:

Clear span (ft): Clear Height (ft): Full Waterway $\left(f t^{2}\right)$ : 
Downstream distance (miles): Town: Year Built:

Highway No. : Structure No. : Structure Type:

Clear span (ft): Clear Height $(f t)$ : Full Waterway $\left(f^{2}\right)$ :

Comments:

No full hydraulics report is available. Just some limited data based on office memoranda. Tail water elevation noted at Q50 of 1142.3. Type 1 stone was recommended as riprap material at this site.

\section{USGS Watershed Data}

Watershed Hydrographic Data Drainage area $(D A) \stackrel{38.40}{\mathbf{3}} \mathrm{mi}^{2}$ Lake and pond area $\mathbf{3 . 0 7}$ $\mathrm{mi}^{2}$

Watershed storage (ST)

Bridge site elevation 8.0 $\%$

Main channel length 1149 $\mathrm{ft}$ Headwater elevation 3049 $\mathrm{ft}$ $10 \%$ channel length elevation $\mathbf{1 1 5 0}$ $\mathrm{ft} \quad 85 \%$ channel length elevation 1360 $\mathrm{ft}$

Main channel slope (S) $23.41 \quad \mathrm{ft} / \mathrm{mi}$

Watershed Precipitation Data

Average site precipitation in Average headwater precipitation in

Maximum 2yr-24hr precipitation event $(124,2)$ in

Average seasonal snowfall (Sn) $\mathrm{ft}$ 


\section{Bridge Plan Data}

Are plans available? $\underline{Y}$ If no, type ctrl-n pl Date issued for construction (MM/YYYY): $\underline{\mathbf{0 2}}$ / 1978

Project Number F - BHF 034 - 3(5)

Minimum channel bed elevation: 1144.3

Low superstructure elevation: USLAB $\underline{1144.95}$ DSLAB $\underline{1144.31}$ USRAB $\underline{1144.31}$ DSRAB $\underline{\mathbf{1 1 4 4 . 9 5}}$

Benchmark location description:

Benchmark \#1 - a chiseled square on top of a boulder, elevation 1147.58, located 60-70 feet left bankward from the left abutment and approximately 40 feet from the centerline of the road on the downstream left overbank area.

Reference Point (MSL, Arbitrary, Other): MSL Datum (NAD27, NAD83, Other): Foundation Type: 1

If 1: Footing Thickness $\underline{\mathbf{2 . 0}}$ Footing bottom elevation: $\underline{\mathbf{1 1 2 9 . 0}}$

If 2: Pile Type:___ (1-Wood; 2-Steel or metal; 3-Concrete) Approximate pile driven length:

If 3: Footing bottom elevation:

Is boring information available? $\underline{\mathbf{Y}}$ If no, type ctrl- $n$ bi Number of borings taken: $\underline{\mathbf{2}}$

Foundation Material Type: 1 (1-regolith, 2-bedrock, 3-unknown)

Briefly describe material at foundation bottom elevation or around piles:

Silt based on the 2 borings, overlain by sand and silty sand.

\section{Comments:}

Other points with elevations provided on the plans are: 1) at the corner of upstream end of upstream left wingwall, elevation 1141.0 feet; and 2) at the corner of upstream end of upstream right wingwall, elevation 1140.5 feet. On both wingwalls, elevations refer to points where wingwall goes from slightly sloping to vertical. The channel has been graded to make the channel bed elevation about 2 feet above the top of the spread footings. There is an approximately 2 foot log mat underneath the spread footings. 


\section{Cross-sectional Data}

Is cross-sectional data available? $\underline{\mathbf{Y}}$

If no, type ctrl-n xs

Source (FEMA, VTAOT, Other)? VTAOT

Comments: Bridge cross section of PREVIOUS STRUCTURE nearest the upstream face at stationing $4+$ 86.5, 13.5 feet from the center line of the roadway over the bridge. The channel base line runs along the left bank perpendicular to the bridge, 7 feet from the left abutment face.



Source (FEMA, VTAOT, Other)? $\quad$ VTAOT

Comments: Bridge cross section for PREVIOUS STRUCTURE nearest the downstream face at stationing $5+13.60,13.6$ feet from the center line of the roadway over the bridge.

\begin{tabular}{|l|l|l|l|l|l|l|l|l|l|l|l|}
\hline Station & $\mathbf{7 . 0}$ & $\mathbf{1 0 . 5}$ & $\mathbf{1 3 . 5}$ & $\mathbf{2 7 . 0}$ & $\mathbf{3 8 . 0}$ & $\mathbf{4 3 . 5}$ & $\mathbf{4 6 . 5}$ & & & & \\
\hline Feature & LCL & $\begin{array}{l}\text { footing } \\
\text { edge }\end{array}$ & $\begin{array}{l}\text { Sub- } \\
\text { footing }\end{array}$ & TD & $\begin{array}{l}\text { sub- } \\
\text { footing }\end{array}$ & $\begin{array}{l}\text { footing } \\
\text { edge }\end{array}$ & LCR & & & & \\
\hline $\begin{array}{l}\text { Low cord } \\
\text { elevation }\end{array}$ & $\mathbf{1 1 4 4}$ & $\mathbf{t 1 1 3 1}$ & $\mathbf{t 1 1 2 9}$ & & $\mathbf{t 1 1 2 9}$ & $\mathbf{t 1 1 3 1}$ & $\mathbf{1 1 4 3 . 5}$ & & & & \\
\hline $\begin{array}{l}\text { Bed } \\
\text { elevation }\end{array}$ & $\mathbf{1 1 3 3}$ & $\mathbf{b 1 1 2 9}$ & $\mathbf{b 1 1 2 7}$ & $\mathbf{1 1 3 2}$ & $\mathbf{b 1 1 2 7}$ & $\mathbf{b 1 1 2 9}$ & $\mathbf{1 1 3 3}$ & & & & \\
\hline $\begin{array}{l}\text { Low cord to } \\
\text { bed length }\end{array}$ & $\mathbf{1 1}$ & & & & & & $\mathbf{1 0 . 5}$ & & & & \\
\hline Station & & & & & & & & & & & \\
\hline Feature & & & & & & & & & & & \\
\hline $\begin{array}{l}\text { Low cord } \\
\text { elevation }\end{array}$ & & & & & & & & & & & \\
\hline $\begin{array}{l}\text { Bed } \\
\text { elevation }\end{array}$ & & & & & & & & & & & \\
\hline $\begin{array}{l}\text { Low cord to } \\
\text { bed length }\end{array}$ & & & & & & & & & & & \\
\hline
\end{tabular}




\section{APPENDIX E: \\ LEVEL I DATA FORM}


U. S. Geological Survey

Bridge Field Data Collection and Processing Form

Qa/Qc Check by: $\mathbf{R B}$ Date: $3 / 27 / 96$

\section{Structure Number}

\section{A. General Location Descriptive}

1. Data collected by (First Initial, Full last name) $\mathbf{J}$. DEGNAN

2. Highway District Number 9

County ESSEX (009)

Waterway ( $($ - 6) NULHEGAN RIVER

Route Number VT 105

3. Descriptive comments:

Located about 7.6 miles west of State Route 105 intersection with State Route 102.
Mile marker $\mathbf{0 0 3 3 4 0}$

Town FERDINAND (25975)

Road Name -

Hydrologic Unit Code: $\mathbf{0 1 0 8 0 1 0 1}$

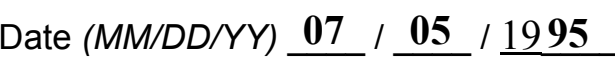

\section{B. Bridge Deck Observations}
4. Surface cover... LBUS 5
RBUS 5
LBDS 5
RBDS 5
Overall 5

(2b us, ds,lb,rb: 1- Urban; 2- Suburban; 3- Row crops; 4- Pasture; 5- Shrub- and brushland; 6- Forest; 7- Wetland)
5. Ambient water surface... US 1
UB 1
DS 1
(1- pool; 2- riffle)

6. Bridge structure type 1 (1- single span; 2- multiple span; 3- single arch; 4- multiple arch; 5-cylindrical culvert; 6- box culvert; or 7- other)
7. Bridge length 44
(feet)
Span length $\underline{42}$
(feet)
Bridge width $\underline{\mathbf{3 5 . 6}}$ (feet)

\section{Road approach to bridge:}
8. LB $\underline{0}$ RB 1
( 0 even, 1- lower, 2- higher)
9. LB 1
RB 1
(1-Paved, 2- Not paved)

10. Embankment slope (run / rise in feet / foot)

US left

4.4:1

US right $\quad 2.8: 1$

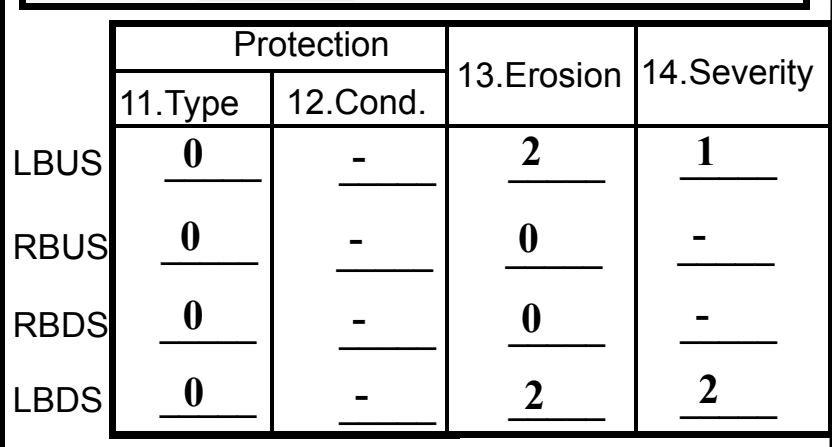

Bank protection types: 0- none; 1- < 12 inches;

2- < 36 inches; 3- < 48 inches;

4- < 60 inches; 5- wall / artificial levee

Bank protection conditions: 1- good; 2- slumped;

3- eroded; 4- failed

Erosion: 0 - none; 1- channel erosion; 2 -

road wash; 3- both; 4- other

Erosion Severity: 0 - none; 1- slight; 2- moderate; 3- severe

\section{Channel approach to bridge (BF):}

15. Angle of approach: $\underline{40}$

16. Bridge skew: 10

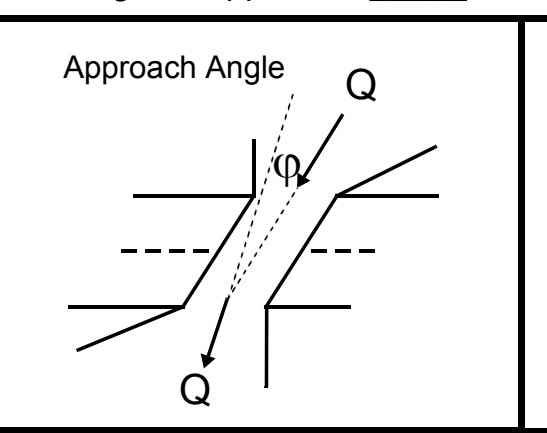

17. Channel impact zone 1:

Where? RB (LB, RB)

Exist? $\mathbf{Y}$ (Yor $N)$

Bridge Skew Angle

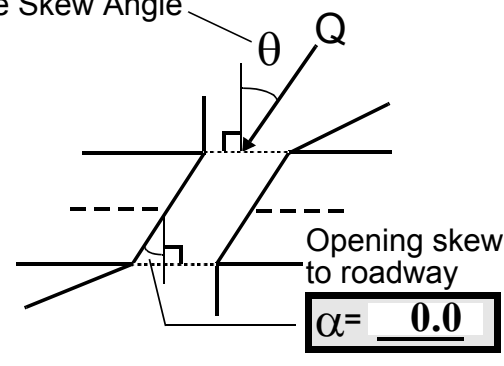

Range? 140 feet $\underline{\text { US }}$

Channel impact zone 2:

Where? LB $(L B, R B)$

Severity 2

Range? $\underline{\mathbf{0}}$ feet US

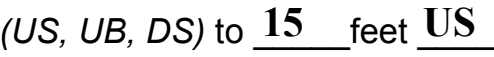

Exist? $\underline{\mathbf{Y}}(\mathrm{Y}$ or $N)$

Severity 1

Impact Severity: 0- none to very slight; 1- Slight; 2- Moderate; 3- Severe 
18. Bridge Type: 1a

1a- Vertical abutments with wingwalls

1 b- Vertical abutments without wingwalls

2- Vertical abutments and wingwalls, sloping embankment

Wingwalls perpendicular to abut. face

3- Spill through abutments

4- Sloping embankment, vertical wingwalls and abutments

1a with wingwalls

Wingwall angle less than $90^{\circ}$.

19. Bridge Deck Comments (surface cover variations, measured bridge and span lengths, bridge type variations, approach overflow width, etc.)

Values reported for \#7 are from VTAOT files. Measured \#7 span length is actually 40 feet.

4. The topographic map has this area marked wetlands but it is currently dry.

\section{Upstream Channel Assessment}

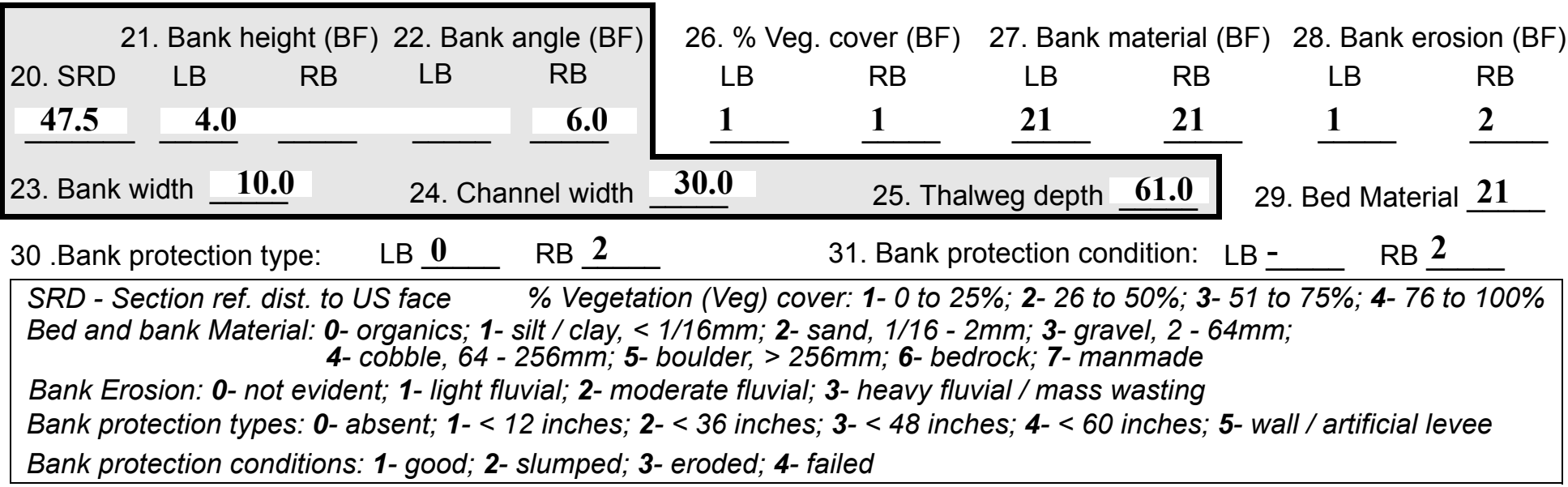

32. Comments (bank material variation, minor inflows, protection extent, etc.):

The bank protection is heaviest 30 feet US to the corner of the upstream right wingwall and right abutment. 
38. Point or side bar comments (Circle Point or Side; Note additional bars, material variation, status, etc.):

39. Is a cut-bank present? $\mathbf{Y}$ ( $Y$ or if $N$ type ctrl-n $c b)$

40. Where? RB (LB or RB)

41. Mid-bank distance: 110

42. Cut bank extent: 140 feet $\underline{\mathbf{U S}}$ (US, UB) to $\underline{\mathbf{5 0}}$ feet $\underline{\mathbf{U S}}$ (US, UB, DS)

43. Bank damage: 3

(1- eroded and/or creep; 2- slip failure; 3- block failure)

44. Cut bank comments (eg. additional cut banks, protection condition, etc.):

The bank condition improves towards the bridge due to stone fill.

\section{Is channel scour present? $\mathbf{Y}$ ( $Y$ or if $N$ type ctrl-n cs)}

47. Scour dimensions: Length $\mathbf{6 5}$

Width 10

Depth : 3

(n)

46. Mid-scour distance: 25

48. Scour comments (eg. additional scour areas, local scouring process, etc.):

This hole has developed along the toe of the stone fill along the right bank upstream.

\section{Are there major confluences? $\mathbf{Y}$ ( $Y$ or if $N$ type ctrl-n $m c$ ) \\ 51. Confluence 1: Distance 140 \\ Confluence 2: Distance - \\ 52. Enters on $\underline{\mathbf{R B}}$ (LB or $R B)$ \\ Enters on - (LB or $R B)$}

54. Confluence comments (eg. confluence name):

50. How many? 1

53. Type 1 (1- perennial; 2- ephemeral)

Type (1- perennial; 2- ephemeral)

The confluence (Stevens brook) is wider but with a shallower slope than the Nulhegan River's main channel.

\section{Under Bridge Channel Assessment}

55. Channel restraint (BF)? LB 2

56. Height (BF)
LB RB
$\mathbf{3 1 . 0}-$
58. Bank width (BF) -
59. Channel width $(\mathrm{Amb})$ (1- natural bank; 2- abutment; 3- artificial levee)

Bed and bank Material: 0- organics; 1- silt / clay, < 1/16mm; 2- sand, 1/16 - 2mm; 3- gravel, 2 - 64mm; 4- cobble, 64 - 256mm; 5- boulder, > 256mm; 6- bedrock; 7- manmade

Bank Erosion: 0- not evident; 1- light fluvial; 2- moderate fluvial; 3- heavy fluvial / mass wasting

64. Comments (bank material variation, minor inflows, protection extent, etc.):

2

$-$ 
65. Debris and Ice Is there debris accumulation?

$(Y$ or $N)$ 66. Where? $\mathbf{N}$

(1- Upstream; 2- At bridge; 3-Both)

67. Debris Potential ( 1- Low; 2- Moderate; 3- High)

68. Capture Efficiency 2

(1-Low; 2- Moderate; 3- High)

69. Is there evidence of ice build-up? 1 (Y or $N)$

Ice Blockage Potential $\mathbf{N}$

(1-Low; 2-Moderate; 3- High)

70. Debris and Ice Comments:

1

The channel meanders and is laterally unstable cutting the banks at most bends. There are mainly young trees, shrubs, and brush on the banks.

\begin{tabular}{|l|c|c|c|c|c|c|c|c|}
\hline Abutments & $\begin{array}{c}\text { 71. Attack } \\
\angle \text { (BF) }\end{array}$ & $\begin{array}{c}\text { 72. Slope } \angle \\
\text { (Qmax) }\end{array}$ & $\begin{array}{c}\text { 73. Toe } \\
\text { loc. (BF) }\end{array}$ & $\begin{array}{c}\text { 74. Scour } \\
\text { Condition }\end{array}$ & $\begin{array}{c}75 . \text { Scour } \\
\text { depth }\end{array}$ & $\begin{array}{c}\text { 76. Exposure } \\
\text { depth }\end{array}$ & 77. Material & 78. Length \\
\hline LABUT & & $\mathbf{1 0}$ & $\mathbf{8 5}$ & $\mathbf{2}$ & $\mathbf{0}$ & $\mathbf{0}$ & $\mathbf{0}$ & $\mathbf{9 0 . 0}$ \\
\hline RABUT & $\mathbf{1}$ & - & $\mathbf{8 5}$ & & & $\mathbf{2}$ & $\mathbf{0}$ & $\mathbf{3 9 . 5}$ \\
\hline
\end{tabular}

Pushed: $L B$ or RB

Toe Location (Loc.): 0- even, 1- set back, 2- protrudes

Scour cond.: 0- not evident; 1- evident (comment); 2- footing exposed; 3-undermined footing; 4- piling exposed; 5- settled; 6- failed

Materials: 1- Concrete; 2- Stone masonry or drywall; 3- steel or metal; 4- wood

79. Abutment comments (eg. undermined penetration, unusual scour processes, debris, etc.):

0

$\mathbf{0}$

1

The abutments protrude from the top of the banks on both sides, but are set back from the bottom of the banks.

80. Wingwalls:

Exist? Material? Scour Scour Exposure $\begin{aligned} & 81 . \\ & \text { Angle? Length? }\end{aligned}$ Condition? depth? depth?

USLWW:

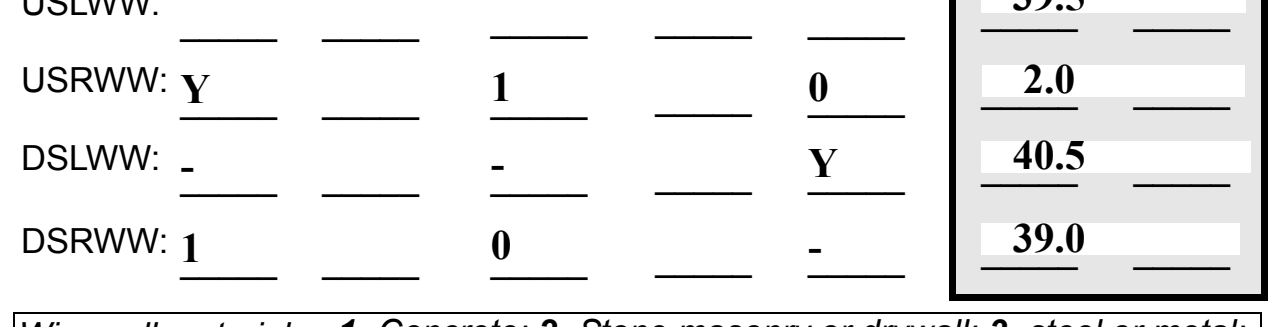

Wingwall materials: 1- Concrete; 2- Stone masonry or drywall; 3- steel or metal; 4- wood

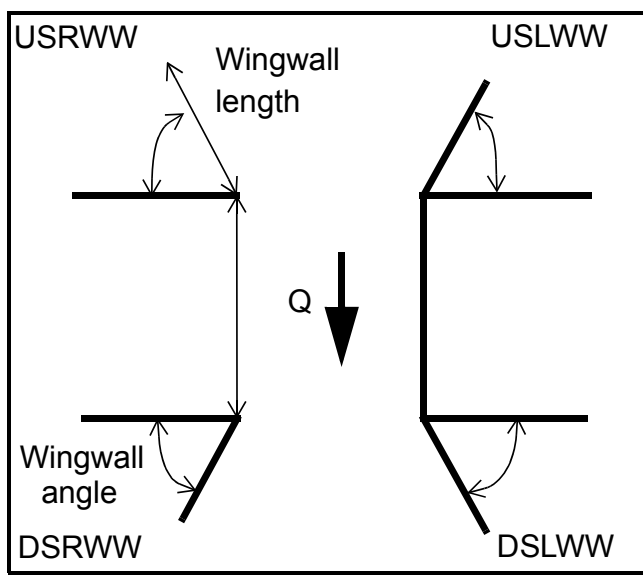

82. Bank / Bridge Protection:

\begin{tabular}{|l|l|l|l|l|l|l|l|c|}
\hline Location & USLWW & USRWW & LABUT & RABUT & LB & RB & DSLWW & DSRWW \\
\hline Type & - & $\mathbf{0}$ & $\mathbf{Y}$ & - & - & $\mathbf{1}$ & $\mathbf{1}$ & $\mathbf{1}$ \\
\hline Condition & $\mathbf{Y}$ & - & $\mathbf{1}$ & - & - & $\mathbf{1}$ & $\mathbf{3}$ & $\mathbf{1}$ \\
\hline Extent & $\mathbf{1}$ & - & $\mathbf{0}$ & $\mathbf{0}$ & $\mathbf{2}$ & $\mathbf{2}$ & $\mathbf{2}$ & - \\
\hline
\end{tabular}

Bank / Bridge protection types: 0- absent; 1- < 12 inches; 2- < 36 inches; 3- < 48 inches; 4- < 60 inches; 
83. Wingwall and protection comments (eg. undermined penetration, unusual scour processes, etc.):

-
-
-
-
-
2
1
1
2
1
1

\section{Piers:}

84. Are there piers? Th (Y or if $N$ type ctrl-n pr)

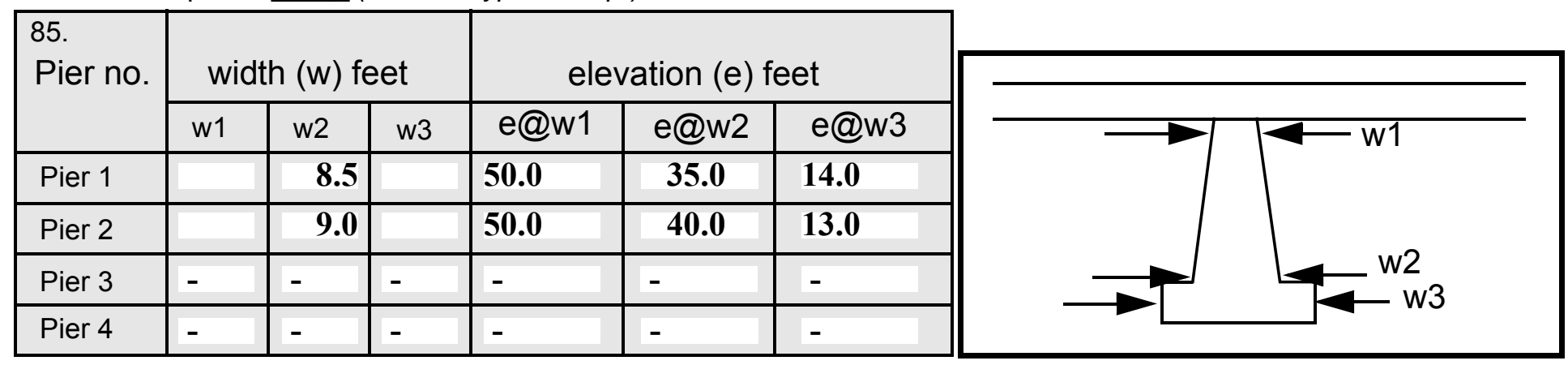

\begin{tabular}{|l|l|l|l|l|}
\hline Level 1 Pier Descr. & \multicolumn{1}{|c|}{1} & \multicolumn{1}{|c|}{2} & 3 & \multicolumn{1}{|c|}{} \\
\hline 86. Location (BF) & e left & to & & - \\
\hline 87. Type & abut & DS & & - \\
\hline 88. Material & ment & as & & - \\
\hline 89. Shape & pro- & the & & - \\
\hline 90. Inclined? & tec- & chan & & - \\
\hline 91. Attack $\angle$ (BF) & tion & nel & & - \\
\hline 92. Pushed & is & cuts & & - \\
\hline 93. Length (feet) & - & - & - & - \\
\hline 94. \# of piles & unde & into & & - \\
\hline 95. Cross-members & r a & the & & - \\
\hline 96. Scour Condition & bar & right & & - \\
\hline 97. Scour depth & from & bank & N & - \\
\hline 98. Exposure depth & US & US. & - & - \\
\hline
\end{tabular}

LFP, LTB, LB, MCL, MCM, MCR, RB, RTB, RFP

1- Solid pier, 2- column, 3- bent

1-Wood; 2- concrete; 3- metal; 4- stone

1- Round; 2- Square; 3- Pointed

Y-yes; $N$ - no

$L B$ or $R B$

0- none; 1- laterals; 2- diagonals; 3- both

0- not evident; 1- evident (comment);

2- footing exposed; 3- piling exposed;

4- undermined footing; 5- settled; 6-failed 
99. Pier comments (eg. undermined penetration, protection and protection extent, unusual scour processes, etc.):

-
-
-
-
-
-
-
-
-
-

100.

\section{E. Downstream Channel Assessment}

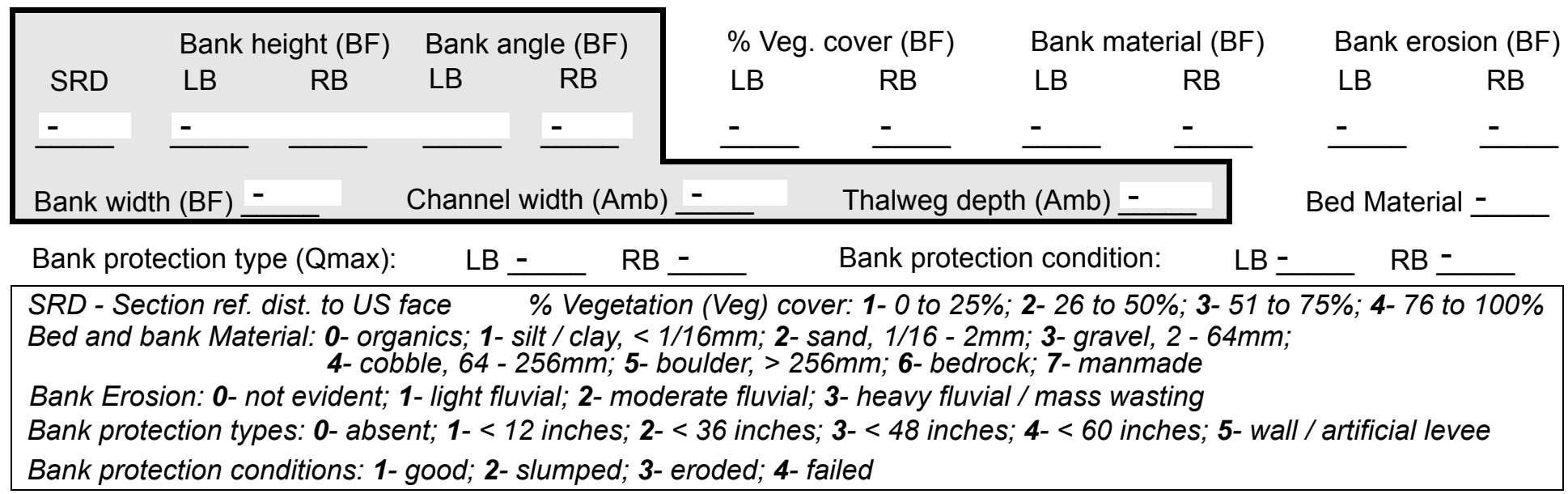

Comments (eg. bank material variation, minor inflows, protection extent, etc.):

-
-
-
-
-
-
-
-
-
-
-
-
-

\section{NO PIERS}

101. Is a drop structure present? ___ ( or $N$, if $N$ type ctrl-n ds) 102. Distance: _ _ feet
103. Drop: - feet
104. Structure material:
(1- steel sheet pile; 2- wood pile; 3- concrete; 4- other)

105. Drop structure comments (eg. downstream scour depth): 
106. Point/Side bar present? $(Y$ or $N$. if $N$ type ctrl-n pb)Mid-bar distance: 1

Mid-bar width: 1

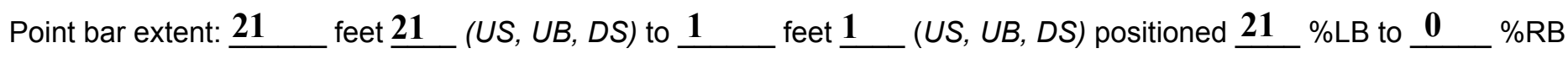
Material: $\mathbf{0}$

Point or side bar comments (Circle Point or Side; note additional bars, material variation, status, etc.):

Is a cut-bank present? ( $Y$ or if $N$ type ctrl-n $c b) \quad$ Where? (LB or $R B)$

Mid-bank distance:

Cut bank extent: feet (US, UB, DS) to feet (US, UB, DS)

Bank damage: (1- eroded and/or creep; 2- slip failure; 3- block failure)

Cut bank comments (eg. additional cut banks, protection condition, etc.):

Is channel scour present? ( $Y$ or if $N$ type ctrl-n cs)

Mid-scour distance: $\mathbf{N}$ Scour dimensions: Length Width NO Depth: DR Positioned $\underline{\text { OP }} \%$ LB to $\underline{\text { ST }} \%$ RB Scour comments (eg. additional scour areas, local scouring process, etc.):

\section{RUCTURE}

Are there major confluences?

Confluence 1: Distance $\mathbf{Y}$

Confluence 2: Distance $\underline{\mathbf{0}}$ En
Confluence comments (eg. confluence name):

DS

40 ( $Y$ or if $N$ type ctrl-n $m c)$ Enters on $\underline{\mathbf{1 0}}$ (LB or RB) Enters on $\underline{\mathbf{U B}}$ (LB or RB)
How many?

Type 10 (1-perennial; 2- ephemeral) Type 15 (1- perennial; 2- ephemeral)

\section{F. Geomorphic Channel Assessment}

107. Stage of reach evolution $\mathbf{6 0}$

1- Constructed

2- Stable

3- Aggraded

4- Degraded

5- Laterally unstable

6- Vertically and laterally unstable 
108. Evolution comments (Channel evolution not considering bridge effects; See HEC-20, Figure 1 for geomorphic descriptors):

2

The channel bar dumps right into the middle of the scour hole and is submerged.

$\mathbf{N}$

$-$

$-$

$-$

$-$

$-$

- 


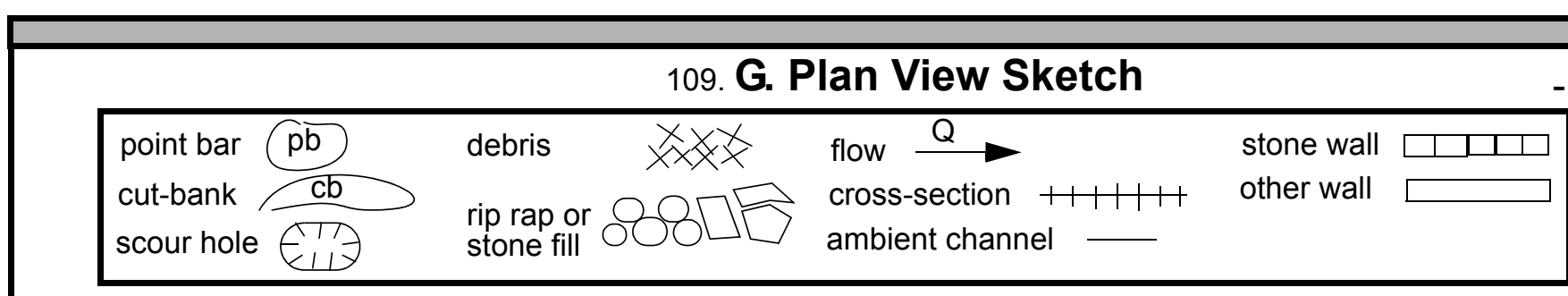


APPENDIX F:

SCOUR COMPUTATIONS 
SCOUR COMPUTATIONS

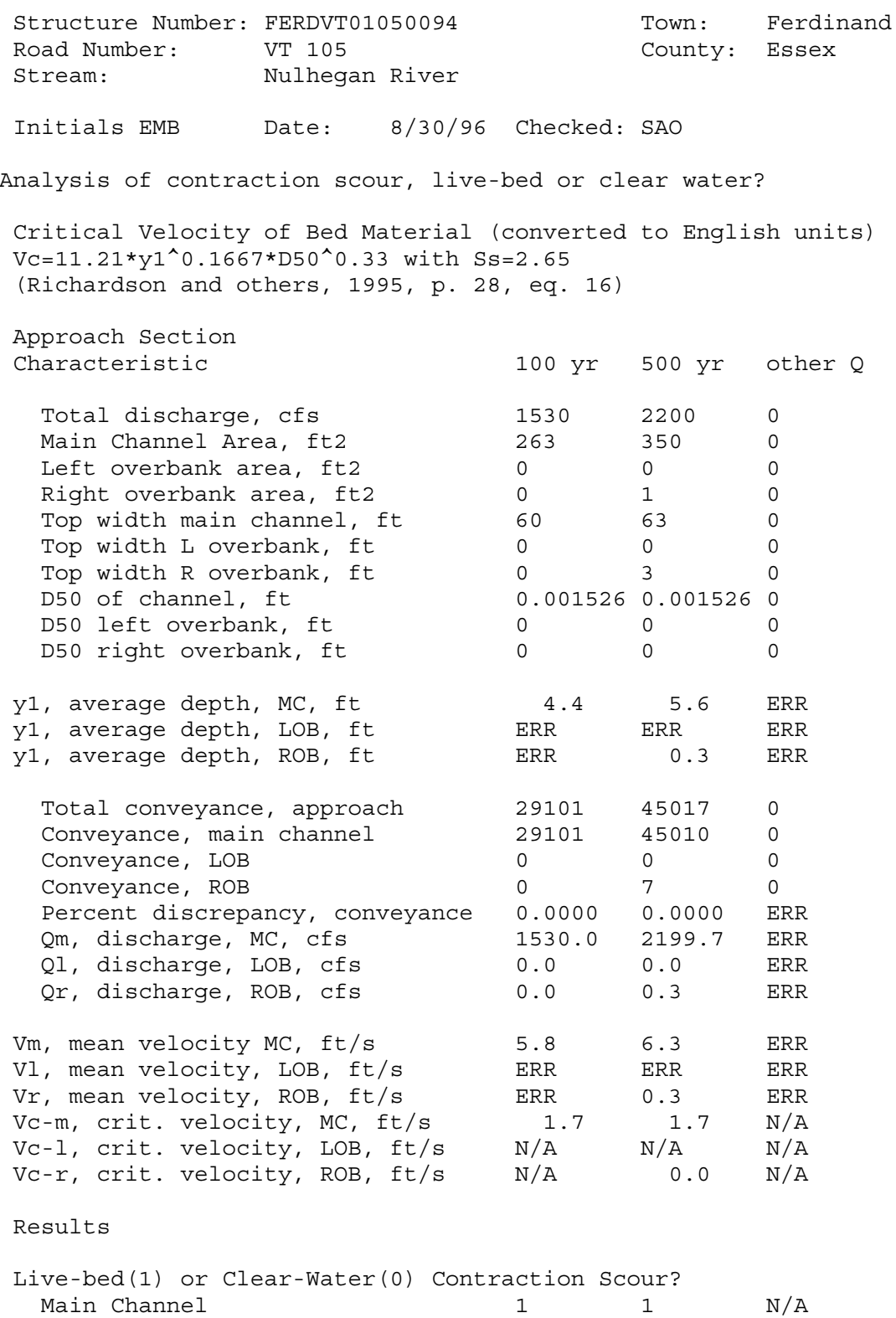




\begin{tabular}{|c|c|c|c|c|c|c|}
\hline \multicolumn{7}{|c|}{ 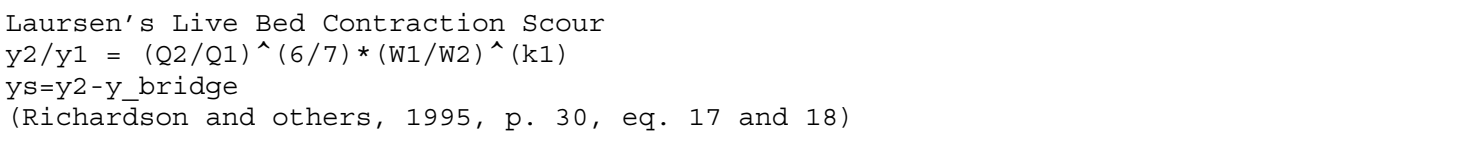 } \\
\hline & Approach & & & Bridge & & \\
\hline Characteristic & $100 \mathrm{yr}$ & $500 \mathrm{yr}$ & Other Q & $100 \mathrm{yr}$ & $500 \mathrm{yr}$ & Other Q \\
\hline Q1, discharge, cfs & 1530 & 2200 & 0 & 1530 & 2200 & 0 \\
\hline Total conveyance & 29101 & 45017 & 0 & 23515 & 32080 & 0 \\
\hline Main channel conveyance & 29101 & 45010 & 0 & 23515 & 32080 & 0 \\
\hline Main channel discharge & 1530 & 2200 & ERR & 1530 & 2200 & ERR \\
\hline Area - main channel, ft2 & 263 & 350 & 0 & 184.5 & 226.5 & 0 \\
\hline (W1) channel width, ft & 60 & 63 & 0 & 38.9 & 39 & 0 \\
\hline (Wp) cumulative pier width, ft & 0 & 0 & 0 & 0 & 0 & 0 \\
\hline w1, adjusted bottom width(ft) & 60 & 63 & 0 & 38.9 & 39 & 0 \\
\hline D50, ft & 0.001526 & 0.001526 & 0 & & & \\
\hline w, fall velocity, ft/s (p. 32) & 0.268 & 0.268 & 0 & & & \\
\hline y, ave. depth flow, ft & 4.38 & 5.56 & $\mathrm{~N} / \mathrm{A}$ & 4.74 & 5.81 & ERR \\
\hline S1, slope EGL & 0.003 & 0.003 & 0 & & & \\
\hline P, wetted perimeter, MC, ft & 63 & 66 & 0 & & & \\
\hline R, hydraulic Radius, ft & 4.175 & 5.303 & ERR & & & \\
\hline $\mathrm{V}^{*}$, shear velocity, ft/s & 0.635 & 0.716 & $\mathrm{~N} / \mathrm{A}$ & & & \\
\hline$V^{*} / \mathrm{w}$ & 2.370 & 2.671 & ERR & & & \\
\hline $\begin{array}{l}\text { Bed transport coeff., } \mathrm{k} 1,(0.59 \text { if } \\
\mathrm{k} 1\end{array}$ & $\begin{array}{l}\mathrm{V} * / \mathrm{W}<0.5 \\
0.69\end{array}$ & $\begin{array}{l}0.64 \text { if } \\
0.69\end{array}$ & $\begin{array}{l}5<\mathrm{V} * / \mathrm{W}<2 ; \\
0\end{array}$ & 0.69 if & $\mathrm{V} * / \mathrm{W}>2.0$ & p. 33 ) \\
\hline $\mathrm{y}^{2}$, depth in contraction, ft & 5.91 & 7.74 & ERR & & & \\
\hline ys, scour depth, ft (y2-y_bridge) & 1.17 & 1.93 & $\mathrm{~N} / \mathrm{A}$ & & & \\
\hline
\end{tabular}




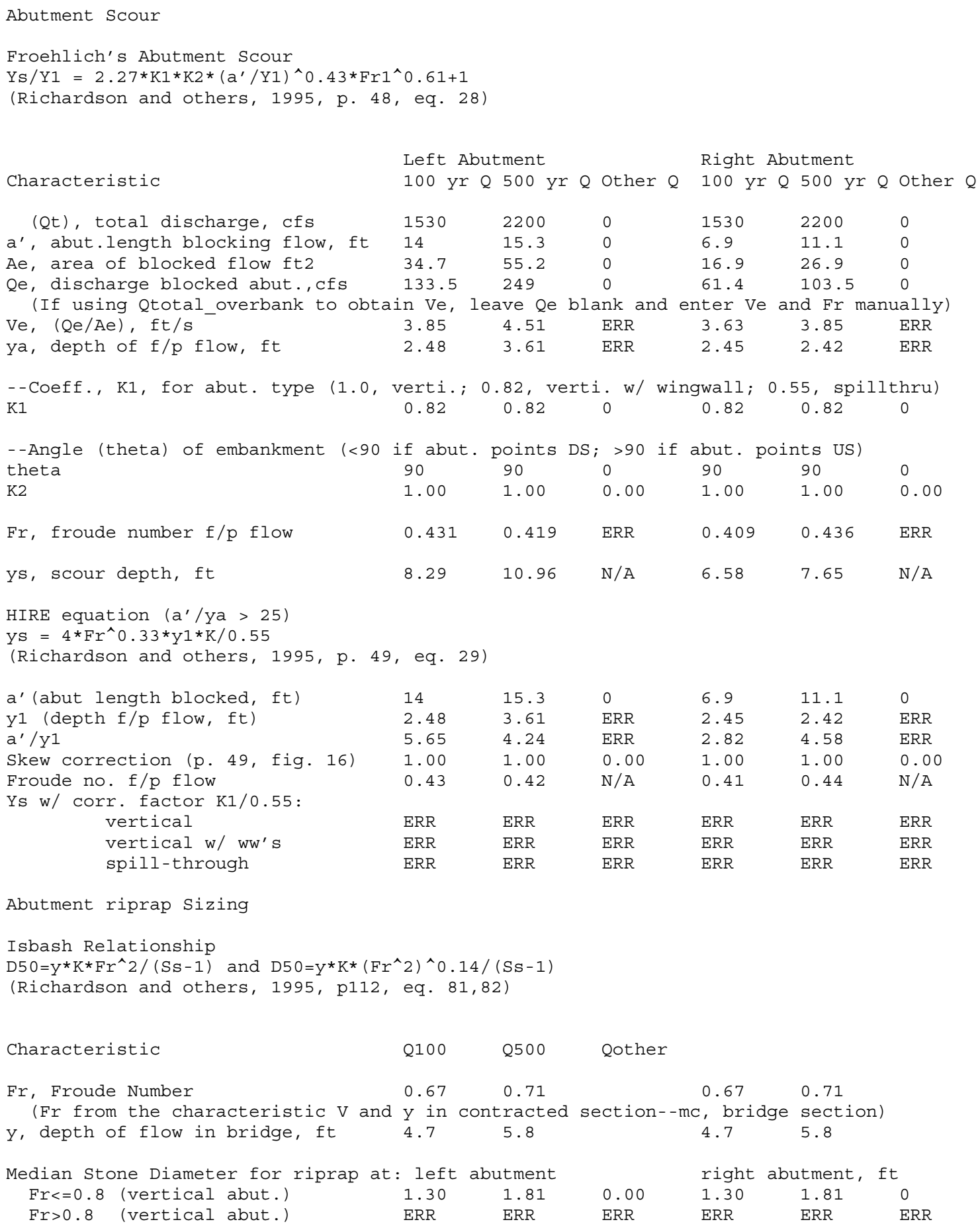

